(1) Nordic Council of Ministers

\title{
Potential Ecodesign Requirements for Textiles and Furniture
}

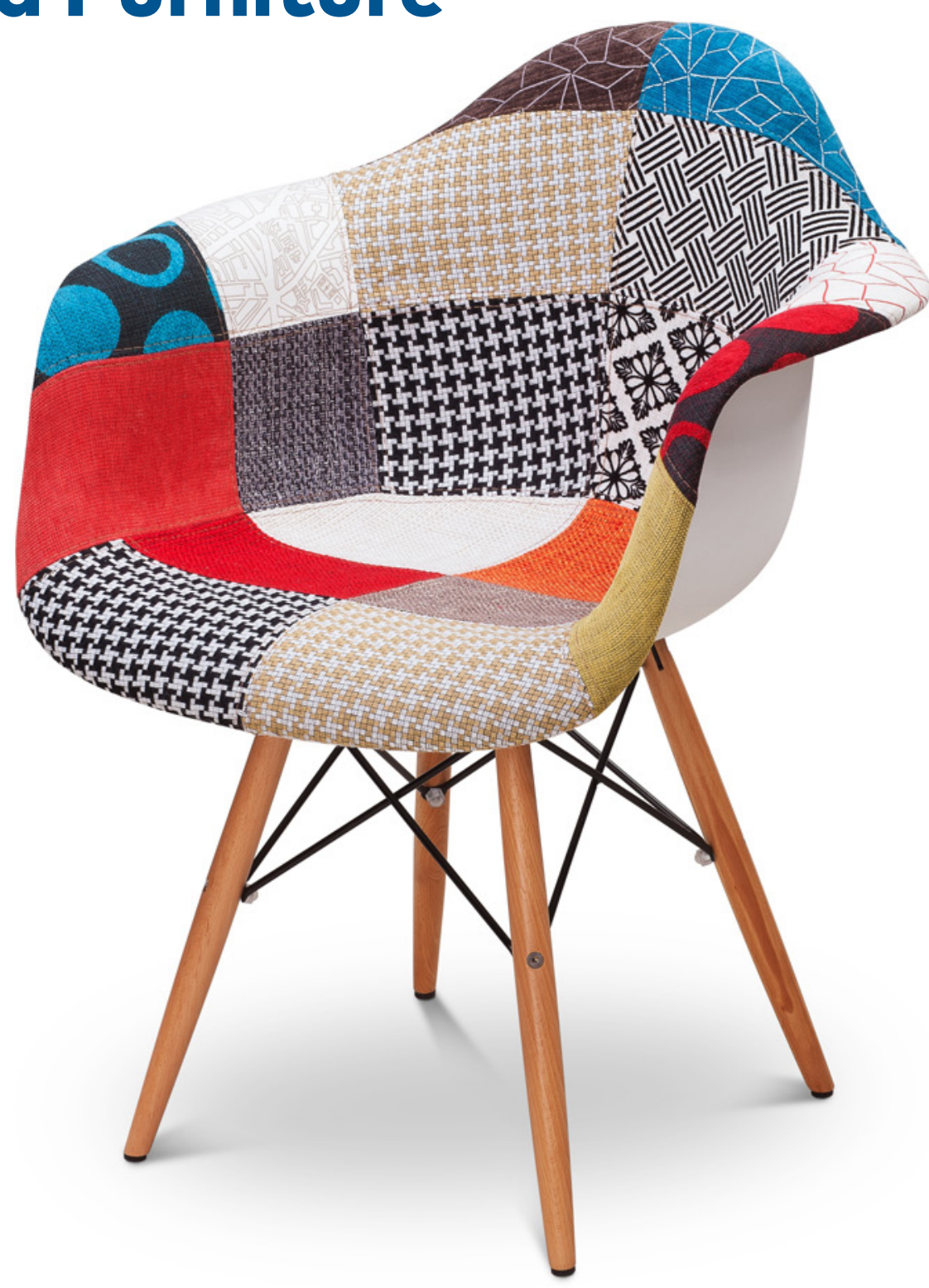




\section{Potential Ecodesign Requirements for Textiles and Furniture}

Bjørn Baver, David Watson, Anja Gylling, Arne Remmen, Michael Hauris Lysemose, Catharina Hohenthal and Anna-Karin Jönbrink

TemaNord 2018:535 
Potential Ecodesign Requirements for Textiles and Furniture

Bjørn Baver, David Watson, Anja Gylling, Arne Remmen, Michael Hauris Lysemose, Catharina Hohenthal and Anna-Karin Jönbrink

ISBN 978-92-893-5631-2 (PRINT)

ISBN 978-92-893-5632-9 (PDF)

ISBN 978-92-893-5633-6 (EPUB)

http://dx.doi.org/10.6027/TN2018-535

TemaNord 2018:535

ISSN $0908-6692$

Standard: PDF/UA-1

ISO 14289-1

(c) Nordic Council of Ministers 2018

Cover photo: Scanpix

Print: Rosendahls

Printed in Denmark

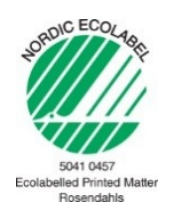

Disclaimer

This publication was funded by the Nordic Council of Ministers. However, the content does not necessarily reflect the Nordic Council of Ministers' views, opinions, attitudes or recommendations.

Rights and permissions

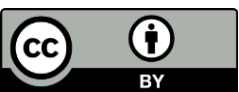

This work is made available under the Creative Commons Attribution 4.0 International license (CC BY 4.0) https://creativecommons.org/licenses/by/4.0

Translations: If you translate this work, please include the following disclaimer: This translation was not produced by the Nordic Council of Ministers and should not be construed as official. The Nordic Council of Ministers cannot be held responsible for the translation or any errors in it.

Adaptations: If you adapt this work, please include the following disclaimer along with the attribution: This is an adaptation of an original work by the Nordic Council of Ministers. Responsibility for the views and opinions expressed in the adaptation rests solely with its author(s). The views and opinions in this adaptation have not been approved by the Nordic Council of Ministers. 
Third-party content: The Nordic Council of Ministers does not necessarily own every single part of this work. The Nordic Council of Ministers cannot, therefore, guarantee that the reuse of third-party content does not infringe the copyright of the third party. If you wish to reuse any third-party content, you bear the risks associated with any such rights violations. You are responsible for determining whether there is a need to obtain permission for the use of third-party content, and if so, for obtaining the relevant permission from the copyright holder. Examples of third-party content may include, but are not limited to, tables, figures or images.

Photo rights (further permission required for reuse):

Any queries regarding rights and licences should be addressed to:

Nordic Council of Ministers/Publication Unit

Ved Stranden 18

DK-1061 Copenhagen K

Denmark

Phone +4533960200

pub@norden.org

\section{Nordic co-operation}

Nordic co-operation is one of the world's most extensive forms of regional collaboration, involving Denmark, Finland, Iceland, Norway, Sweden, and the Faroe Islands, Greenland and Åland.

Nordic co-operation has firm traditions in politics, economics and culture and plays an important role in European and international forums. The Nordic community strives for a strong Nordic Region in a strong Europe.

Nordic co-operation promotes regional interests and values in a global world. The values shared by the Nordic countries help make the region one of the most innovative and competitive in the world.

The Nordic Council of Ministers

Nordens Hus

Ved Stranden 18

DK-1061 Copenhagen K, Denmark

Tel.: +4533960200 www.norden.org

Download Nordic publications at www.norden.org/nordpub 


\section{Contents}

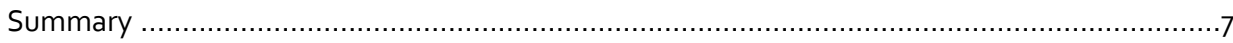

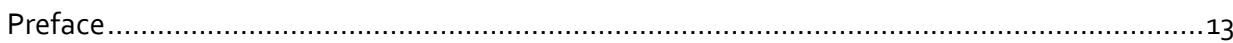

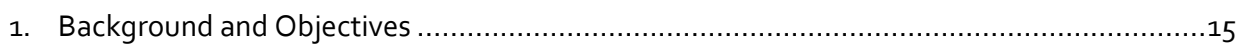

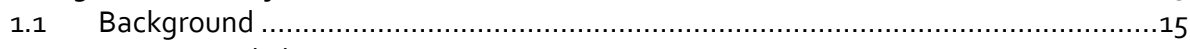

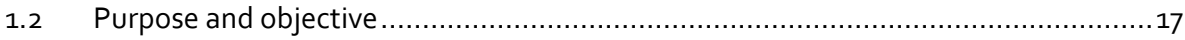

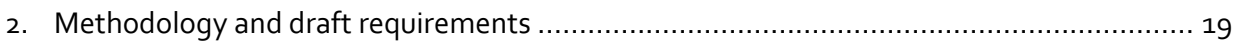

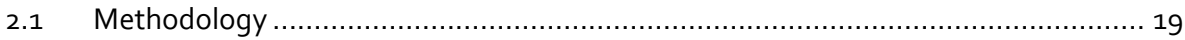

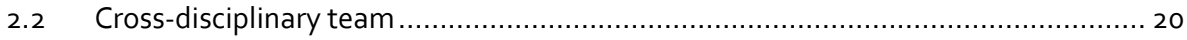

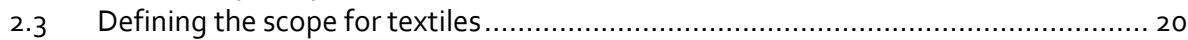

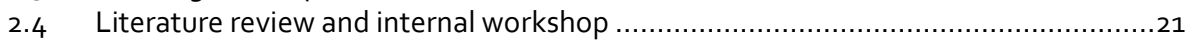

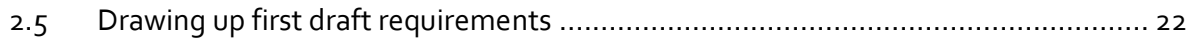

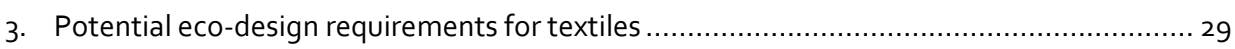

4. Potential environmental benefits of the proposed requirements for textiles......................41

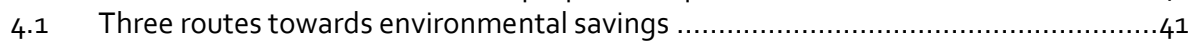

4.2 From eco-design requirements to environmental savings ............................... 42

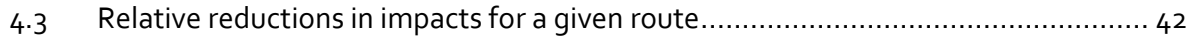

4.4 Strength of link between requirements and saving routes ................................ 45

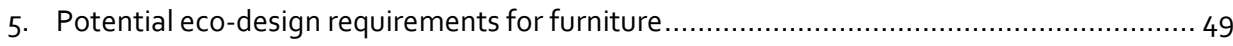

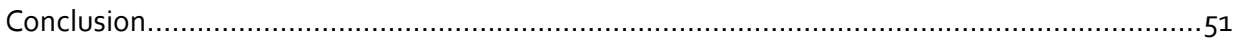

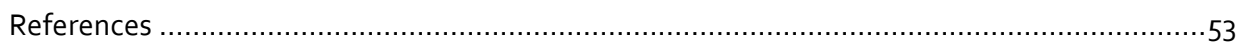

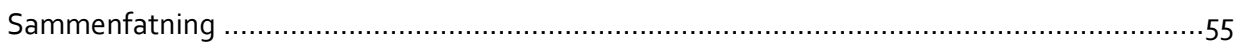

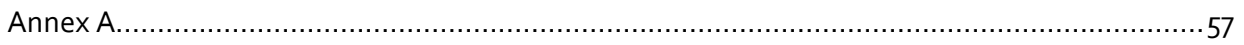




\section{Summary}

Better design can increase resource efficiency by encouraging products that are durable, easy to repair, upgrade and remanufacture and where recovery of valuable materials and components is enabled at end-of-life. The Ecodesign Directive has so far mostly been used to improve the energy efficiency of products but has strong potential to encourage material resource efficiency. The European Commission issued a request for the development of standards for material efficiency requirements under the directive. Material efficiency requirements are beginning to enter draft requirements for energy-related products.

This type of requirement can also be applied with potentially significant environmental gains to non-energy related product groups. One potential candidate is clothing and textile products. There is considerable wastage in the value chain of clothing and textile products due to fast fashion, dropping quality and relatively low repair and reuse rates.

This project aimed to demonstrate how resource-related ecodesign requirements can be drawn up for non-energy-related products using textiles as an example. A "light application" of the approach was subsequently applied to the furniture sector.

Material resource efficiency criteria found in ecolabels can provide a starting point for ecodesign requirements. However, while the former establish inspirational benchmarks for best-performing products, the latter establish minimum standards that all products must meet. Thus, requirements under the Ecodesign Directive should be less stringent, should develop over time to allow gradual improvement of products and advanced warning should be provided to producers of future requirements. In addition to criteria in ecolabels and green procurement guidance, inspiration for ecodesign requirements was drawn from research on material efficiency and circular economy in textiles.

A long list of potential requirements was drawn up and developed further in consultation with experts and industry representatives.

Proposed requirements address durability, reuse, repair and recyclability. In some cases technical criteria need to be supplemented by information/declaration requirements. ${ }^{1}$ For example, design for ease of recyclability will only have a positive effect if 1 ) the product finds its way to a recycler, and 2) the recycler is aware of how it should be handled. The former can be enabled by telling consumers where to discard unwanted clothing; the latter by providing information for recyclers on material content and appropriate recycling methods.

${ }^{1}$ Refer to need for compliance with different regulations provided in the report. 
A further necessary condition is that there is a market for the recovered materials.

To create this market, we also suggest criteria for minimum content of recycled material in new products. A summary of proposed requirements is given below.

Table 1: List of potential ecodesign requirements for textiles

\begin{tabular}{|c|c|c|c|c|c|}
\hline \multirow[t]{2}{*}{ Requirement } & \multirow{2}{*}{$\begin{array}{l}\text { Themes } \\
\text { addressed }\end{array}$} & \multirow[t]{2}{*}{ Description } & \multicolumn{3}{|c|}{ Type of requirement } \\
\hline & & & Informative & Threshold & Other \\
\hline $\begin{array}{l}\text { 1. Declaration of, } \\
\text { and/or minimum } \\
\text { threshold for recycled } \\
\text { content }\end{array}$ & Recycling & $\begin{array}{l}\text { Textile products must carry a visible label with a declaration of the } \\
\text { percentage by weight content of recycled materials AND/OR } \\
\text { Products within [stated fibre group] must contain a minimum of X\% } \\
\text { recycled material by weight. }\end{array}$ & $\checkmark$ & $\checkmark$ & \\
\hline $\begin{array}{l}\text { 2. Durability of } \\
\text { fasteners }\end{array}$ & Durability & $\begin{array}{l}\text { Fasteners should be able to be fastened and unfastened } X \text { number of } \\
\text { times without failure. }\end{array}$ & & $\checkmark$ & \\
\hline $\begin{array}{l}\text { 3. Availability of spare } \\
\text { parts }\end{array}$ & $\begin{array}{l}\text { Durability } \\
\text { Reparability }\end{array}$ & $\begin{array}{l}\text { The producer must make spare parts available for } X \text { years after } \\
\text { product has been on sale, or alternatively must provide spare parts } \\
\text { with the product (e.g. extra buttons, thread of correct colour, } \\
\text { replacement zips etc.). }\end{array}$ & & & $\checkmark$ \\
\hline $\begin{array}{l}\text { 4. Design for } \\
\text { disassembly }\end{array}$ & $\begin{array}{l}\text { Durability } \\
\text { Reparability } \\
\text { Reusability } \\
\text { Recyclability }\end{array}$ & $\begin{array}{l}\text { The product logo, buttons and zips should be removable within } X \\
\text { seconds. Seams should be disassembled within } X \text { seconds but } \\
\text { without reducing durability under normal use and care. Instructions } \\
\text { should be provided on how to do this. }\end{array}$ & & $\checkmark$ & \\
\hline $\begin{array}{l}\text { 6. Provision of detailed } \\
\text { bill of materials }\end{array}$ & $\begin{array}{l}\text { Recyclability } \\
\text { Recycled } \\
\text { content }\end{array}$ & $\begin{array}{l}\text { The product must include, or link to, a list of all materials included in } \\
\text { the product and at what level they are pure or mixed with other } \\
\text { materials, and the share they make up by weight of the product } \\
\text { down to a chosen threshold (e.g. } 1 \% \text { ) } \\
\text { Products that are made from a single material (with tolerance } \\
\text { around } 98 \% \text { ) must be stamped with a "100\% recyclable" stamp. }\end{array}$ & $\checkmark$ & & \\
\hline $\begin{array}{l}\text { 7. Care and } \\
\text { maintenance labelling }\end{array}$ & $\begin{array}{l}\text { Durability } \\
\text { Reparability }\end{array}$ & $\begin{array}{l}\text { The product must be accompanied with information (or link to } \\
\text { information) on recommended care and maintenance tips that can } \\
\text { prolong the lifetime of the product (and reduce use phase impacts). }\end{array}$ & $\checkmark$ & & \\
\hline $\begin{array}{l}\text { 8. Dimensional } \\
\text { changes during } \\
\text { washing and drying }\end{array}$ & Durability & $\begin{array}{l}\text { Between minus } X \% \text { and plus } X \% \text { for woven products, and durable } \\
\text { non-wovens, other knitted products. }\end{array}$ & & $\checkmark$ & \\
\hline $\begin{array}{l}\text { 9. Colour fastness to } \\
\text { washing }\end{array}$ & Durability & $\begin{array}{l}\text { Colour-fastness to washing must be at least } X \text { (test score) for colour } \\
\text { change and at least } X \text { (test score) for staining. }\end{array}$ & & $\checkmark$ & \\
\hline $\begin{array}{l}\text { 10. Colour fastness to } \\
\text { perspiration (acid, } \\
\text { alkaline) }\end{array}$ & Durability & $\begin{array}{l}\text { Colour fastness must be at least } X \text { (test score for colour change and } \\
\text { staining). }\end{array}$ & & $\checkmark$ & \\
\hline $\begin{array}{l}\text { 11. Colour fastness to } \\
\text { wet rubbing }\end{array}$ & Durability & Colour fastness to wet rubbing must be at least $X$ (test score). & & $\checkmark$ & \\
\hline $\begin{array}{l}\text { 12. Colour fastness to } \\
\text { dry rubbing }\end{array}$ & Durability & Colour fastness to dry rubbing must be at least $X$ (test score). & & $\checkmark$ & \\
\hline $\begin{array}{l}\text { 13. Colour fastness to } \\
\text { light }\end{array}$ & Durability & Colour fastness to light must be at least $X$ (test score). & & $\checkmark$ & \\
\hline $\begin{array}{l}\text { 14. Resistance to pilling } \\
\text { and abrasion }\end{array}$ & Durability & Fabrics shall resist pilling of a minimum of at least $X$ (test score). & & $\checkmark$ & \\
\hline $\begin{array}{l}\text { 15. Chemical content - } \\
\text { organic fluorine }\end{array}$ & Recyclability & $\begin{array}{l}\text { The total content of organic fluorine must not exceed } X \mu \mathrm{g} \mathrm{F}-/ \mathrm{g} \\
\text { garment. }\end{array}$ & & $\checkmark$ & \\
\hline
\end{tabular}


This set of requirements is intended to give inspiration to the development of requirements by a future working group under the Ecodesign Directive. No distinct thresholds have been proposed for the threshold-based requirements. Determining feasible thresholds requires intensive consultation with market stakeholders and not least a political process during which the strictness of future ecodesign criteria for textiles can be decided in light of other important parameters and prioritisations.

Threshold-based standards require testing and documentation standards. These exist for most of the proposed requirements but would need to be developed for Requirement 4.

There are some issues for which ecodesign requirements are less appropriate. An example is subjective causes for discarding of clothing such as style, fashion or boredom. However, wear and tear and technical failures account for $50-60 \%$ of discards. Requirements 2-3 and 7-15 tackle these.

Finally, care must be taken to ensure that a requirement that strengthens one resource efficiency theme does not weaken another. Requirement 1 on recycled content, for example, strengthens markets for recycling but can potentially weaken technical durability, giving net environmental impacts. This risk must be considered when setting thresholds.

The study also considered how to assess the environmental benefits of proposed requirements. There are three broad routes via which the proposed requirements for textiles will give reductions in impacts over the lifecycle of textiles:

- Extend the active lifetime of products and offset new production;

- Offset the extraction of virgin materials through use of recycled materials;

- Altering laundering habits to reduce water and energy use.

The magnitude of environmental savings for a given environmental impact category can be approximated as follows:

- Environmental savings = Environmental footprint of all consumed textiles $x$ Potential percentage reductions for a given route $x$ Strength of link between requirement and route $x$ Share of total textiles affected.

Using such an approach, an upper limit for the greenhouse gas savings of the set of proposed requirements if implemented at EU level, was estimated at 85 million tonnes $\mathrm{CO}_{2}$-equiv. per year. The achieved benefits will depend on levels set for threshold requirements and responses to declarations.

A "light application" of the criteria development methodology was applied to furniture. The resulting draft requirements given below have not undergone consultation with industry stakeholders. 
Table 2: List of potential ecodesign requirements for furniture

No. Potential requirement Comment

$1 \quad$ Fitness for use

Furniture shall be considered as fit for use if it complies with the requirements set out in the latest versions of relevant standards on durability, dimensional requirements, safety and strength.

2 Expected lifespan

Product manufacturer must declare the expected lifespan of the product by normal use.

\section{Provision of spare parts}

The furniture manufacturer shall make spare parts available to customers for a period of at least $\mathbf{X}$ years from the date of delivery of the product.

$4 \quad$ Design for disassembly

Simple and illustrated instructions regarding the disassembly and

replacement of damaged components/ parts/ materials shall be provided. Disassembly and replacement operations shall be capable of being carried out using basic manual tools and unskilled labour.

6 Consumer information/instructions The consumer shall be provided with i) a detailed description of the best ways to dispose of the product ii) Guidance on cleaning and maintaining the product; iii) Assembly and disassembly instructions.

$7 \quad$ Bill of materials

Producers must provide an overall bill of materials stating the total weight of the product unit, how the weight is split among different materials, and placement of different components. Plastics must be defined by type and physically marked. Recycled materials must also be declared.

$9 \quad$ Packaging materials

Packaging must consist of readily recycled material and/or materials taken from renewable resources or be a multi-use system.
Third part verified/developed standards can secure a continuous improvement raising the bottom level. ISO standards normally correspond to around 5-10 years of use.

Could also serve as a precursor to a requirement on prolonged warranty.

The present standards that address durability simulate 5-10 years real life usage. Some companies have their own testing equipment and may run longer cycles (tests).

Making spare parts available can enable repair and with this a longer life of the product.

Design for disassembly is essential in enabling repair and recycling since many products on the market today are difficult to separate into different materials for recycling or to repair.

There is a potential conflict between disassembly and durability/expected lifetime since joints with bolts and screws tend to be more prone to fatigue and loosening with time than fixed joints.

In order to ensure a longer active life of the product guidance on maintenance shall be provided to the consumer, furthermore the consumer should be encouraged to reuse etc. if comprehensive instead of disposal.

Information on the contents of recycled materials could increase the use of such materials (in order to meet consumer demands).

Information criterion criteria to allow industry to adapt and invest with a long term perspective.

Definition of plastic parts and recycled parts will ease recycling.

There are considerable environmental perspectives in increasing the use of recycled/renewable packaging materials. 
The project has shown that it is possible to formulate relevant both quantitative and qualitative ecodesign criteria for non-energy related product groups with the following methodology:

- Setting a cross-disciplinary team.

- Defining the scope for textiles.

- Literature review and internal workshop.

- First draft requirements.

- Stakeholder consultation.

- Preparation of final ecodesign requirements.

The litmus test of the criteria will be a more thorough market dialogue revealing the sector's response to individual criteria, and to negotiate ambitious but feasible threshold levels for these criteria in the short and longer term. 


\section{Preface}

In this report potential ecodesign requirements that can be drawn up for non-energyrelated products are in focus. Textiles are here used as an example, and a light application of the approach has subsequently been applied to the furniture sector.

The project was carried out in the period from January 2017 to January 2018 by experts from organisations in three Nordic countries.

- Bjørn Baver, David Watson \& Anja Charlotte Gylling, PlanMiljø, Denmark

- Arne Remmen, Aalborg University, Denmark

- Michael Hauris Lysemose, KADK, Denmark

- Catharina Hohenthal, VTT, Finland

- Anna-Karin Jönbrink, Swerea, Sweden

The representatives from industry and textile/ecodesign experts who assisted with the development of proposals for ecodesign requirements are listed in Annex A.

The project was initiated and financed by the Nordic Council of Ministers and led by its Working Group for Sustainable Consumption and Production.

The process was guided by a steering group from organisations in four Nordic countries:

- Gert Hansen, Danish Environmental Protection Agency

- Ari Nissinen, Finnish Environment Institute

- Trine-Lise Torgesen, Norwegian Environment Agency

- Lina Kinning, Swedish Energy Agency

- Cecilia Matsson, Swedish Environmental Protection Agency

The SCP working group hereby would like to express its gratitude to everyone who has contributed to the project.

Stockholm 26.04.2018, on behalf of the NCM SCP working group (HKP gruppen)

Annica Carlsson, Chair of the NCM SCP working group, Senior Advisor, Swedish Environmental Protection Agency 


\section{Background and Objectives}

\section{$1.1 \quad$ Background}

The transition to a more circular economy is an essential contribution to develop a sustainable, low carbon, resource efficient and competitive economy in the EU. In a circular economy the value of products, materials and resources is maintained in the economy for as long as possible, and the generation of waste is minimised.

The issue of resource/material scarcity has come to the forefront of the environmental agenda in recent years, and the Ecodesign Directive is considered as one of the key existing EU policy instruments that can be brought to bear on these issues (Dalhammar et al., 2014). However, the Directive has not yet fulfilled its potential to deliver on its initial purpose to be a product lifecycle-oriented instrument promoting eco-design practices for all relevant environmental aspects. Bundgaard et al. (2015) found information-based requirements relevant to resource efficiency and/or end-of-life in 16 of the 23 implementing measures that existed at the time of the study, but found very few minimum criteria related to these issues.

For several years the Sustainable Consumption and Production Group (HKP) of the Nordic Council of Ministers has worked to identify opportunities for how the Ecodesign Directive can be applied beyond energy consumption in a product's use phase. Better design can make products more durable, easier to repair, upgrade or remanufacture and easier to recover valuable materials and components end-of-life (European Commission, 2015a). This will reduce the demand on renewable and non-renewable material resources.

The European Commission (2015a) promises in Closing the Loop - the EU Action Plan for the Circular Economy to emphasise circular economy aspects in product design requirements under the Ecodesign Directive in the future, to promote a better design of electronic products. This need is also recognised in the Commission's current Working Plan (2016-2019) for implementing the Ecodesign Directive. The working plan focuses as the previous did on energy efficiency but notes that "in future, ecodesign should make a much more significant contribution to the circular economy, for example by more systematically tackling material efficiency issues such as durability and recyclability".

One of the first implementing actions for the circular economy action plan was a request by the Commission to the European Standardisation Organisations for material efficiency requirements, for energy-related products (ERP) under the Ecodesign Directive (Europen Commission 2015b). This standards are under development and six working groups have been established within the following areas: 
- Terminology.

- General method for the assessment of the durability of products

- Upgradability, ability to repair, facilitate reuse, use or reused components.

- General method for assessing the ability to remanufacture.

- Recyclability, recoverability, RRR index, recycling, use of recycled materials.

- Documentation and/or marking regarding information relating to material efficiency of the product.

Meanwhile, material efficiency requirements are gradually playing a role in the revision of existing eco-design requirements for ERPs. The latest draft requirements for washing machines, for example, include requirements for ease of dismantling to enable recycling, and spare part availability for minimum seven years after the production date.

This application of the Ecodesign Directive to encourage material efficiency and circular economy can also be applied to non-energy related product groups.

One potential product group candidate is clothing and textile products. The textile sector is an important part of the European manufacturing sector generating a turnover of EUR 166 billion annually. ${ }^{2}$ However, the consumption and use of clothing and footwear is responsible for $4^{-6 \%}$ of the EU's environmental footprint (European Environment Agency, 2013).

A key means for reducing the environmental impacts of textile products is to increase the active lifetime of these products via single or multiple users. However, fast fashion trends are pushing use patterns in the other direction and are also associated with reducing quality in the absence of minimum quality standards. ${ }^{3}$ Moreover, recycling of textile garments is challenged by widespread use of mixed fibres, dyes and other finishes that are not compatible with recycling, and lack of markets for recycled fibres (Elander and Ljungkvist, 2016). While some brands are designing for longevity, ${ }^{4}$ fewer are designing for repair and recyclability (Watson et al. 2017).

These challenges have been recognised by the Nordic sustainable textile action plan "Well-dressed in a Clean Environment". Due to the global nature of the textile industry, specifying minimum durability, recyclability and reparability design standards at national or even Nordic level has limited potential (Watson and Bundgaard Nielsen, 2016).

Setting minimum standards at EU level, on the other hand, would have significant influence on products put on the internal market. The Nordic Council of Ministers can potentially have influence on the development of such standards under the Ecodesign Directive.

\footnotetext{
${ }^{2}$ https://ec.europa.eu/growth/sectors/fashion/textiles-clothing/eu_en

3 Matheny, R. and Hernandez, A.: Slow fashion in retail environments: why storytelling is critical for product longevity. In Plate Conference 2017.

4 See also Claxton, S., Cooper, T., Goworek, H., Hill, H., McLaren, A. and Oxborrow, L.: Pilling in knitwear: a clothing

longevity problem beyond design. Plate Conference 2017.
} 


\subsection{Purpose and objective}

This project has the overall purpose to develop an approach for how the Ecodesign Directive can be used to target material resource considerations for product groups other than the energy-related products that the directive currently addresses. The project focuses on textiles, hereby following up on many other Nordic initiatives aiming at a sustainable textile sector.

More specifically, the project aims to demonstrate how resource-related ecodesign requirements can be drawn up for textiles with specific focus on durability, reparability, reusability and recyclability - and taking into consideration chemical challenges.

The project includes also a "light application" of the approach to the furniture sector.

\section{Quick overview of the Ecodesign Directive}

The Ecodesign Directive adopted in 2005 and revised in 2009 has been an effective tool for improving the energy efficiency of products by eliminating the worst performing products from the market.

For various groups of energy related products the Directive sets out mandatory minimum requirements that are applicable to all products produced in or imported to the EU within that group.

Requirements for different product groups have been drawn up, prioritised according to the energy relevance of the products in the group. The product groups for which requirements are to be established are listed in a working plan for a set period. So far three successive Working Plans have been set out: 2009-2011, 2012-2014, 2016-2019. Requirements have been established for 40 product groups.

The Directive's potential for application to non-energy related themes has come under the spotlight in recent years with Nordic countries at the forefront (e.g. Dalhammar et al., 2014 and Bundgaard et al., 2015). 


\section{Methodology and draft requirements}

\subsection{Methodology}

Already existing requirements relevant to material resource efficiency can be found in ecolabel specifications (such as the EU Ecolabel and the Nordic Swan) and EU Green Public Procurement criteria. These can be used as a potential departure point for material resource related requirements for products under the Ecodesign Directive (ED). However, according to Bundgaard et al., (2015) care must be taken when considering the transfer of criteria from ecolabel specifications to ecodesign product requirements, since these are two distinct policy instruments with different target groups.

Ecolabels are aimed at pulling products' environmental performance from the top by setting standards that top runners can aspire to. They rely upon consumer preference and a market pull. ecodesign requirements on the other hand typically improve environmental performance from the bottom by setting minimum standards that all products within a given category must meet (see Figure 1).

Figure 1: Product Interventions - Overall approach

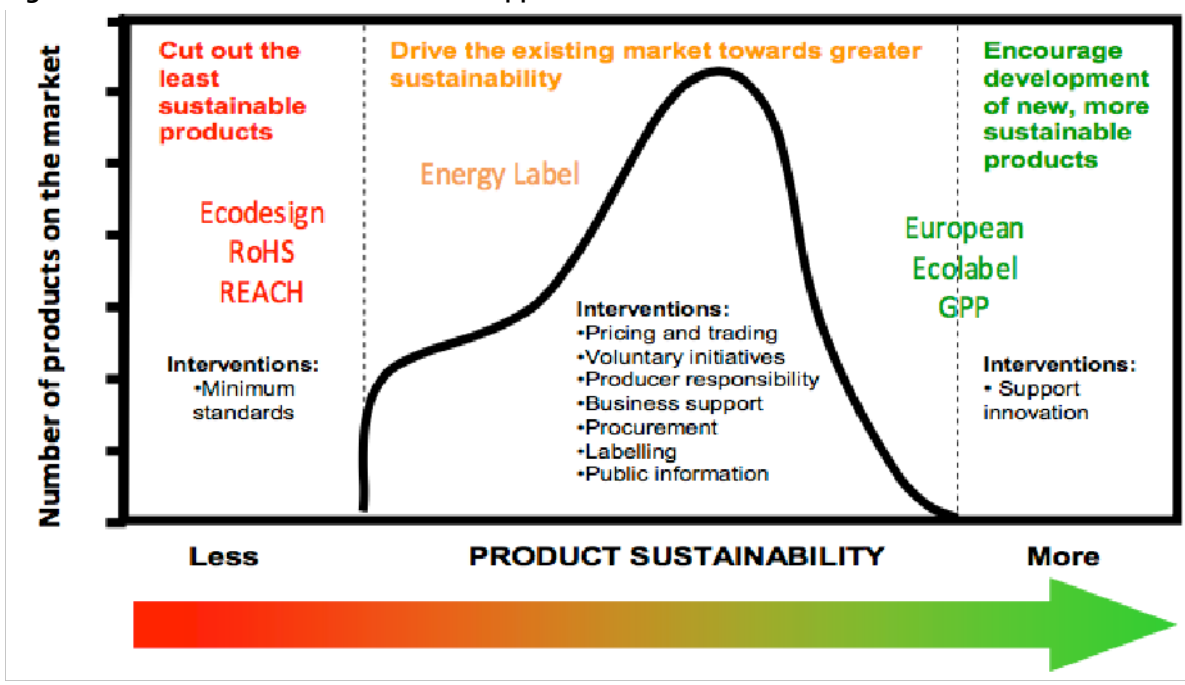

Source: Galatola, Michele, DG ENV, EU Commission.

Thus, in general, requirements set in an implementing instrument under the Ecodesign Directive must be less stringent than criteria in an Ecolabel. Moreover, ecodesign requirements should develop over time to allow gradual improvement of products and advanced warning of changing requirements must be given to allow producers to 
implement changes. Finally, care must be taken not to set standards which unwittingly exclude products which otherwise have other environmental advantages.

Ecolabels and GPP criteria for textiles and furniture do not necessarily cover all potential material resource relevant requirements that could be specified for these product groups. The basis for other requirements can be found in research or through discussions with experts and industry representatives.

Potential requirements for durability, reusability, reparability and recyclability were developed via the following steps:

1. Setting a cross-disciplinary team.

2. Defining the scope for textiles.

3. Literature review and internal workshop.

4. First draft requirements.

5. Stakeholder consultation.

6. Qualitative environmental assessment.

7. Preparation of final ecodesign requirements.

\subsection{Cross-disciplinary team}

The team (see authors) included competence from the most relevant research disciplines: textiles' environmental characteristics, relevant resource saving initiatives within the textile sector, chemicals/hazardous substances, and knowledge of EU product regulation (not least the Ecodesign Directive). In addition, the knowledge base was supplemented by literature searches, consultations with experts and a full day workshop with 15 competent participants.

\subsection{Defining the scope for textiles}

The first step in the project was to define the scope of resource efficiency elements that should be addressed by ecodesign requirements for textiles and the types of products that should be considered.

Resource efficiency has been an element of efforts to improve the environmental performance of textile production for many years, but much of the more recent resource efficiency thinking with respect to the lifecycle of textiles has been influenced by the circular economy agenda. Closing the Loop (European Commission, 2015) the European Commission's action plan for the circular economy, covers a wide range of issues including resource efficiency in production processes, collaborative consumption, more circular waste management systems and end of waste criteria. The chapter directly relevant to ecodesign requirements is that on product design.

Under the product design chapter the Commission recognises that "better design can make products more durable or easier to repair, upgrade or remanufacture. It can 
help recyclers to disassemble products in order to recover valuable materials and components. Overall, it can help to save precious resources".

Thus, design for durability and a longer life, ease of reparability and upgrading, and ease of disassembly to enable material recovery, are key elements that should be covered by ecodesign requirements for textiles and any other products. Moreover, as identified by Watson et al. (2017), design for ease of recyclability, should be supplemented by policy measures that create a market for secondary materials. Thus ecodesign requirements for textiles can also include requirements that increase recycled content in new products.

With respect to product types it was decided to cover clothing and household textiles as included under Combined Nomenclature $(\mathrm{CN})^{5}$ 2-digit-codes 61,62 and part of 63 .

\subsection{Literature review and internal workshop}

We carried out a review of the following documents and others to identify potential requirements under the themes identified above:

- Nordic (Swan) Ecolabel requirements for textiles, hides/skins and leather (Nordic Ecolabel, 2012).

- EU Ecolabel for textile products (European Commission, 2014).

- Global organic textile standard version 4.0 (GOTS) criteria (GOTS IWG, 2014).

- Bra Miljöval criteria for textiles (Swedish Society for Nature Conservation, 2012).

- EU green public procurement criteria for textiles (EU Commission, 2017).

- Addressing resource efficiency through the Ecodesign Directive (Dalhammar et al., 2014).

- Making Clothing Last (Laitala et al., 2015).

- Integration of resource efficiency and waste management criteria in European product policies (Ardente et al., 2012).

- Conference on Product Lifetimes and the Environment (PLATE 2017).

- German Environment Agency 2017. Obsolescence - Political strategies for improved durability of products.

Literature highlights that Ecodesign Directive requirements must necessarily be less stringent and ought to include and give early warnings of gradually tightening of requirements in order to gradually remove worst performing products. Ecolabel criteria on the other hand aim at providing benchmarks for best-performing products. Ecolabel criteria for textiles (and the underlying environmental assessments) can nevertheless

5 https://ec.europa.eu/taxation_customs/business/calculation-customs-duties/what-is-common-customs-tariff/combinednomenclature_en 
provide us with inspiration to types and formulation of potential ecodesign requirements.

Relevant criteria found in the ecolabels and in green public procurement (GPP) documents are for the most part their minimum criteria and address:

- Product durability (resistance to dry and wet rubbing, resistance to pilling, formretention after laundering, and so on).

- Use of recycled fibres.

Issues that are not included under any of the eco-labels are design for recyclability and design for reparability. Some inspiration can be found from literature generated under a range of Nordic and European programs such as the European Clothing Action Plan (ECAP) ${ }^{6}$ program, UK WRAP's Sustainable Clothing Action Plan, 7 the Nordic Council of Ministers (2015) roadmap towards a sustainable textile industry and other Europeanfunded or industry led initiatives. ecodesign criteria that address resource efficiency issues for other types of products - including computers, imaging equipment, windows and floors - in GPP and ecolabel criteria and the Green Electronics Council's EPEAT catalogue ${ }^{8}$ have also been used for inspiration.

Findings from the literature review were gathered in a long list of potential requirements. Under each potential requirement the team prepared proposals for which types of textiles this requirement would best be applied and identified potential existing testing procedures and accompanying documentation needs.

\subsection{Drawing up first draft requirements}

In the process of drawing up potential ecodesign requirements, a number of questions are relevant: what types of themes should be addressed, what requirements can be developed under each theme, which types of products are relevant for each requirement, how should requirements be formulated, and how it can be proved whether products live up to these requirements.

The main themes for the requirements were as mentioned durability, reparability, reusability, ease of recyclability and use of recycled content (and taking into consideration chemical aspects). Products which include improvements in any of these broad areas will have the effect of reducing the lifecycle resource use of clothing and home textiles, provided that the changed product characteristics are taken advantage of:

- For example, a more physically durable product will only give environmental gains if use is made of this extended lifetime. If, however, the original owner simply

\footnotetext{
${ }^{6}$ http://www.ecap.eu.com/

7 http://www.wrap.org.uk/sustainable-textiles/scap

${ }^{8}$ http://www.epeat.net/
} 
becomes tired of it and disposes of it anyway, its additional lifetime will only be utilised should systems be in place to recirculate it to a new owner;

- Similarly, design for recyclability will only have a positive effect if 1 ) the product finds its way to a recycler and isn't just disposed of in mixed waste bound for the landfill or incinerator and 2) the recycler is aware of its recyclability characteristics.

Some of these necessary links can be taken into account via additional requirements, e.g. requirements for information declarations. Others will need to be addressed by other types of policy.

There are two main types of requirement that can be included for a product group under the Ecodesign Directive: minimum/maximum thresholds and demands for the provision of information. ${ }^{9}$

- Minimum/maximum thresholds - these are concrete requirements for a minimum or maximum level of some kind of variable. In the case of textiles this could be minimum recycled content by weight, number of washes a garment should be resilient to, the minimum number of times a zipper can be zipped without failing etc. The threshold can also be set at zero i.e. the prohibition of a certain type of chemical. The threshold formulation can include a stepwise progression.

- Obligatory provision of information - a classic example of this is the obligatory energy-labelling of electrical goods in the scale from $A+++$ to $F$. This labelling is aimed at influencing consumers to purchase the more eco-efficient products. Obligatory information can also be aimed at other actors. For example, a bill of materials, or information on how a product can be disassembled can be aimed at recyclers or repairers. ${ }^{10}$

The advantage of thresholds is that the environmentally worst products will be eliminated from the market. The advantage of provision of information is that an information instrument can be adjusted relatively easily in response to technological developments as they arise. The disadvantage is that there is no guarantee that the information will have the required effect, i.e. consumers may decide to ignore an information label.

Below we break down each theme into various sub-themes, which can be addressed by individual requirements.

\footnotetext{
${ }_{9}$ All requirements should comply with, among others, the EU Directive 2005/29/EC - the "Unfair Commercial Practices Directive".

${ }_{10}^{10}$ Following regulation (EU) No 1007/2011, it is not prohibited to state on a label or marking, that a textile product is made up from recycled fibres. The use of the word "recycled", however, must be kept separate from the declaration of fiber content. For example, the name "recycled wool" is not listed in the regulation, only "wool". Consequently, the word "recycled" must be displayed separately. Furthermore, care must be taken to ensure that the information is neither deceptive nor misleading to consumers (i.e. green washing claims), see Directive 2005/29/EC concerning unfair business-toconsumer commercial practices, the UCPD. The latter is true for any type of label and/or information given to the consumers. (Joséphine Slotte, Lawyer, Swedish Consumer Agency 2018).
} 


\subsubsection{Design for durability}

The active lifetime of a garment or other textile product is determined by a wide range of factors. Some of these are technical failures within the product itself; others concern changes in the wearer's body size or shape while further factors are subjective, concerning style and fashion issues. A number of researchers have studied the background reasons for discarding of clothing (though not other textiles).

Laitala et al. (2015) mapped out 71 different reasons given by a sample of Norwegians for discarding clothing, grouped under seven different themes: changes in the garment; size and fit issues; functional shortcomings; taste-related unsuitability; situational reasons; fashion or style changes; other.

They found that the reasons for discarding differed by gender and age: men were more likely to discard clothing because of functional failures or shortcomings in the garment; for women's and especially children's size and fit issues became important. Nevertheless, for all adults, failures in the garment itself represented the cause of discard for close to (women) or just over (men) half the discarded clothing.

A review by Laitala (2014) of five studies carried out around the world found significantly varying importance of product wear and tear, compared to style and fashion, and size and fit issues, depending on the sample group. Another study, being the study with by far the largest sample size, Ungerth and Carlsson (2011), found that wear and tear issues accounted for $60 \%$ of discards. Since requirements under the Ecodesign Directive can mostly only address product specific wear and tear issues along with functionality (see Table 3) it is reassuring that these remain the key reasons for discarding among adults. 
Changes in the garment (wear and tear)

The fabric begins to pill

Parts of the fabric wear out

The seams break

Fasteners such as zips, buttons fail

The colour fades or changes

The product changes shape

The fabric becomes stained

Functional shortcomings

Uncomfortable/itches

Fasteners don't stay closed

Gives static electricity

Not waterproof

The product no longer fits the owner

because the owner changes shape or is

growing (child)

\author{
These factors can be addressed by \\ product design for strength and \\ durability. Ecolabel criteria exist \\ for example on resistance to \\ colour change under various types \\ of strain (wet rubbing, dry rubbing \\ etc.); resistance to shape change; \\ resistance to pilling.
}

These factors can be addressed by

selecting good quality materials

and for designing for functionality

and can potentially also be

addressed by ecodesign

requirements. There are,

however, no examples of this

under ecolabels and GPP criteria.

Products can be designed with stretch, or with other features that make them adaptable to changes in shape and size of the wearer.

These can be addressed partially by making use of classic design.
The Ecodesign Directive is not the right instrument to address subjective style issues. It should primarily be used to demand characteristics that can readily be tested and documented. ${ }^{11}$

Fashion taste or boredom

No longer fashionable

No longer fits own style

Bored with the garment

\subsubsection{Design for reparability}

As with the durability theme, the intention with design for reparability is to increase the active lifetime of products. Textiles do not have many components that can fail, but one important example is fasteners. Readily removable and replaceable fasteners could assist in cheaper repairs of garments. Furthermore, availability of replacement components (in this case fasteners) can be a subject of ecodesign requirements.

$A$ requirement could also be made for the provision of replacement buttons and other fasteners, along with needle and thread to allow home repair.

For other product groups, modular design is an important design aspect that allows for easier reparability as well as functional upgrades. This could potentially be used in clothing by allowing removal and replacement of elements such as elbows or knees, which are more likely to wear out. However, it can be difficult to envisage ecodesign requirements that could require such modularity for clothing and textiles.

\footnotetext{
${ }^{11}$ Although ecodesign requirements can potentially be used to influence behaviour via information-based labels.
} 


\subsubsection{Design for reusability}

Reusability means that the garment can readily be re-circulated to a new owner via existing business models such as second hand shops or new types of sharing or recirculation business models such as leasing or online clothing libraries. Such business models and the development of systems for recirculation are emerging, and along with them the recognition that the economic viability of such models are enhanced by clothing design which fits with these systems (see e.g. Elander et al., 2017). Products can be designed for reusability.

Durability is of course the central element for reusability and has already been covered under 4.4.1. However, there are other elements that further enable use by multiple users. One of these is removability of logos or labels, very relevant to 1) professional uniforms, linen, towels etc. that have been adorned with the company's logo and which the company would like to have removed before reuse; and 2) unsold clothing collections that are to be donated but which the original brand does not wish to compete with in markets.

Design for ready removal of logos and labels is being developed by a number of companies via, for example, use of threads that dissolve under application of certain chemicals, exposure to microwaves or other means.

\subsubsection{Design for ease of recyclability}

What constitutes recyclability is dependent on current recycling technology. As technologies develop, products that were not recyclable ten years ago may be recyclable now. Therefore, requirements within this area will somehow need to take account of future potential developments.

Recycling of textiles into new textiles is inhibited by many factors. ${ }^{12}$ These include the following:

- Use of mixed fibres - a natural fibre is mixed with a synthetic fibre. An example are polyester-cotton fabrics; ${ }^{13}$

- Lack of information on materials - hindering recyclers to use the correct recycling technology;

- Non-removable elements made of other materials - such as zips and other fasteners, labels etc.;

- Persistent functional chemicals such as flame-retardants, anti-bacterial finishes which can give risk of contamination of recovered fibres and subsequent 2nd generation recycled products and/or can be harmful to staff in recycling facilities; ${ }^{14}$

- Dyes/finishes that inhibit chemical recycling processes.

\footnotetext{
${ }_{12}^{12}$ See e.g. Elander and Ljungqvist (2016) and Watson et al. (2017).

${ }_{13}$ The fibres cannot be readily separated; research programmes are making rapid advances in chemical recycling.

${ }_{14}$ These can give health risks if used for the wrong 2 nd generation product (Swedish Government 2015; Schmidt et al., 2016).
} 


\subsubsection{Inclusion of recycled content}

This is covered by a number of ecolabels and is a direct way of encouraging increased circularity of materials. In the case of textiles, minimum thresholds must be fitted to the fibre type. Where fibres can only be recovered mechanically, for example in wool and cotton, fibre lengths are shortened by the recovery process and must be mixed with virgin fibres to provide necessary yarn strength. The recycled content thresholds are low for cotton recovered from post-consumer products, higher for cotton recovered from pre-consumer waste and for mechanically recovered wool, and higher still for remelted polyester (Watson et al. 2017).

Synthetics recovered from chemical recycling processes can be broken down into their building blocks and then re-made into new fibres ready for use in new products without any need to mix with virgin materials.

It may also be necessary to differentiate between use of materials recovered from pre-consumer waste and post-consumer waste since the latter is more difficult to use, but contributes more to a circular economy. Moreover, if pre-consumer waste is given equal weight by a requirement, this risks encouraging deliberate production of preconsumer waste in factories for use in new products.

\subsubsection{Chemical aspects}

Requirements under the Ecodesign Directive may not conflict with or duplicate limits and restrictions found in other EU policy instruments, and the life cycle approach of REACH already to a wide degree ensures that chemical issues are taken care of in product regulation. However, in this project the Danish EPA has found it relevant to investigate the degree to which the Ecodesign Directive can regulate chemical substances (based on the substances' inherent properties) with the specific aim to enhance the options for recycling of the textiles - which is different from the aim of REACH.

An example of a criterion of this nature has been included in our proposals for ecodesign requirements with the purpose of opening a discussion within important fora of the relevance of including chemical requirements in this context.

\subsubsection{List of requirements}

A draft list of requirements was developed to address the sub-themes discussed under each of the themes above. For each requirement the following information was developed: rationale for inclusion; source in literature; scope of textiles to be addressed; potential for a threshold-based or information-based requirement; potential conflicts with other requirements; existence of testing procedures.

\section{Stakeholder consultation}

The approach in the EU to the development of eco-design requirements includes a relatively lengthy consultation period with industry, NGOs and other affected stakeholders where both types, formulation and also thresholds and testing and documentation procedures for requirements are discussed and negotiated. 
Involvement of stakeholders in the present methodology has consisted of a facilitated consultation with a smaller group of industry front-runners, textile experts and other stakeholders during a workshop to receive inputs concerning formulation, need, risks and benefits of the suggested ecodesign requirements.

The workshop was held on 2 May 2017 at the Danish EPA in Copenhagen (a list of workshop participants can be found in Annex A). Under the workshop the team presented draft requirements and the experts and stakeholders worked in small groups on a number of these providing inputs in the form of:

- Opportunities and challenges presented by the requirement.

- Conflicts with other requirements - an example would be where design for ease of recyclability undermined durability of a product.

- Alternative requirements which would avoid challenges and conflicts.

- Relevant testing and documentation standards.

- Formulation of the requirements.

- Which textile groups should it address in the initial phase.

- Other comments/concerns.

At the workshop, the consultant team gathered many useful inputs that allowed us to refine and filter our proposals for requirements. The workshop also created attention in the Nordic textile sector regarding the possibilities to design for recyclability, durability, reparability, and reusability and allowed for exchange of experiences between textile producers, brands and recyclers. 


\section{Potential eco-design requirements for textiles}

The tables below present our proposed requirements for textiles covering garments and home textiles with $\mathrm{CN}$ 2-digit codes 61,62 and $6_{3}$ (part of) produced in, or imported to, the EU. These requirements have emerged from the process described in Chapter $2 .{ }^{15}$

For each requirement we include the following kinds of information:

- Formulation of the requirement.

- Broad theme(s) addressed by the requirement i.e. durability, reparability, recyclability etc.

- Type of requirement i.e. threshold, information-based, other.

- Rationale for the requirement.

- Relevant product types to be addressed by the requirement.

- Testing and documentation standards.

- Comments on scope, challenges in implementation, potential conflicts and synergies with other eco-design aspects.

This set of requirements is intended to give inspiration to the development of requirements by a future working group under the Ecodesign Directive. It has not been possible or relevant to suggest specific thresholds at this point of time.

A start threshold, and perhaps a rolling development of that threshold with time in further editions of the ecodesign requirements, would be the subject of detailed negotiations between the Ecodesign Directive working group, the European Commission, the textile industry and other important stakeholders. Agreed thresholds are likely to differ for different kinds of fibres and different types of products e.g. relevant requirements for underwear will differ widely from relevant requirements for outdoor jackets.

15 The proposed requirements are in line with the recommendations of the very recent UmweltBundesamt Scientific Opinion Paper Obsolescence - Political strategies for improved durability of products, 2017. 


\begin{tabular}{|c|c|c|c|c|}
\hline \multirow{2}{*}{$\begin{array}{l}\text { Requirement(s): } \\
\text { Textile products must carry a visible label } \\
\text { with a declaration of the percentage by } \\
\text { weight content of recycled materials } \\
\text { AND/OR } \\
\text { Products within (stated fibre group) must } \\
\text { contain a minimum of } X \% \text { recycled } \\
\text { material by weight }\end{array}$} & Relevant product type: & \multicolumn{3}{|c|}{ Type of requirement: } \\
\hline & \multirow[t]{2}{*}{$\begin{array}{l}\text { Testing/documentation } \\
\text { options: } \\
\text { Global Recycle Standard } \\
\text { and Recycled Claim } \\
\text { standard }^{16}\end{array}$} & \multirow[t]{2}{*}{$\begin{array}{l}\text { Informative } \\
x\end{array}$} & \multirow[t]{2}{*}{$\begin{array}{l}\text { Threshold } \\
\mathrm{x}\end{array}$} & \multirow[t]{2}{*}{ Other } \\
\hline $\begin{array}{l}\text { Broad theme addressed: } \\
\text { Use of recycled content }\end{array}$ & & & & \\
\hline
\end{tabular}

\section{Rationale}

Requiring a minimum content of recycled material could further stimulate the collection of used textiles and the development of recycling technologies and could also potentially stimulate design for recycling. The same could also be true of a requirement to state the recycled content of products provided that consumers positively favoured products with recycled content. As well as providing environmental benefits increased collection (reuse) and recycling of textiles and other products for use in new products could potentially bring new sorting and waste recovery industries to Europe.

\section{Comments on scope, challenges and conflicts}

- There was general agreement that declarations would be preferred to thresholds, due to wide differences in functional needs (durability, stretch etc.) of different products and the degree to which these functions might be affected by recycled content. A potential approach could be to begin with a declaration, followed by a threshold if the declaration proved to have little effect.

- If thresholds were used these could in first stages be limited to the most readily accessible recycled content such as polyester and cellulose fibres. Polyester especially since inclusion of (chemically) recycled content does not challenge durability (see below).

- Recycled content can conflict with durability (though not for chemically recycled fibres) and thus could risk undermining environmental gains. Extended lifetimes give greater environmental gain than use of recycled content. Inclusion of recycled fibres is perhaps most relevant for rapidly discarded fast fashion and least relevant for textiles whose active lifetime is determined by technical durability e.g. bed-linen, towels, basic underwear etc.

- There is potentially a need to differentiate between pre- and post-consumer textile recycling. Otherwise there is a risk that companies could produce pre-consumer waste on purpose just to be able to declare use of this in recycled content. A solution might be to include a separate ecodesign criterion for maximum waste level in production processes of textile products.

- Traceability of recycled content can be an issue although $3^{\text {rd }}$ party standards do exist for this. There would also be a need for control of hazardous content in recycled content. This can also potentially be solved via $3^{\text {rd }}$ party certification.

- There may be a need to include measures to exclude environmentally disadvantageous recycled materials (also other than those containing hazardous chemicals) from contributing to the declared recycled content. This would require e.g. LCA-based evidence of disadvantageous processes.

- Need to ensure that recycled materials are used for proper functions. Use in textiles may not always be the most optimal route for recycled waste.

- EU Regulation 1007/2011 must be taken into account with regards to the option of specific labelling of recycled contents etc.

\footnotetext{
${ }^{16}$ See Textile Exchanges standards here: https://textileexchange.org/integrity/
} 


\begin{tabular}{|l|l|l|l|l|}
\hline 2. Durability of fasteners & \multicolumn{3}{|c|}{ Type of requirement: } \\
\hline $\begin{array}{l}\text { Requirement: } \\
\begin{array}{l}\text { Fasteners should be able to be } \\
\text { fastened and unfastened X number } \\
\text { of times without failure }\end{array}\end{array}$ & $\begin{array}{l}\text { Relevant product type: } \\
\text { Garments with fasteners } \\
\text { Home textiles with fasteners }\end{array}$ & Informative & Threshold & Other \\
\cline { 2 - 3 } $\begin{array}{l}\text { Broad theme addressed: } \\
\text { Durability }\end{array}$ & $\begin{array}{l}\text { Testing/documentation options: } \\
\text { D2061-03 ASTM international for } \\
\text { zippers }\end{array}$ & & & \\
\hline
\end{tabular}

\section{Rationale}

Fasteners are often one of the first things to fail on jackets, trousers, shirts etc. Buttons are relatively easy to sew back on but zippers and poppers can be much more difficulty and a failed zip will often mean a discarded garments before the rest of the garment has shown signs of wear.

\section{Comments on scope, challenges and conflicts}

- Suppliers of fasteners would need to provide warranties that they met these standards. YKK zippers are already provided such guarantees. These and other similar standards could provide the basis for thresholds or alternatively could act as the final target for gradually more restrictive standards.

- Consumers should be informed of the warranties so that they can return items for which fasteners had failed for repair/replacement.

- This requirement should be linked to that of provision of spare parts (no. 3).

\section{Availability of spare parts}

\section{Requirement:}

The producer must make spare parts available

for $x$ years after product has been on sale, or

alternatively must provide spare parts with the

product (i.e. Extra buttons, thread of correct

colour, replacement zips etc.)

Broad theme addressed:

Durability

Reparability
Relevant product types:

Garments with

fasteners/accessories

Home textiles with

fasteners/accessories

Testing/documentation

options:

Proof of availability of

parts

\section{Rationale}

Providing access to spare parts and accessories to enable easy repairs can encourage consumers to repair rather than discard.

\section{Comments on scope, challenges and conflicts}

- A similar requirement was implemented in 2015 by a decree in France. ${ }^{17}$ The decree puts new requirements on retailers to inform consumers about the availability of spare parts. Manufacturers, in turn, are required to deliver the parts needed for repairs within two months.

${ }_{17}$ Décret $n^{\circ} 2014-1482$ du 9 décembre 2014 relatif aux obligations d'information et de fourniture concernant les pièces détachées indispensables à l'utilisation d'un bien

https://www.legifrance.gouv.fr/affichTexte.do?cidTexte=JORFTEXTo0o029881868\&dateTexte=\&categorieLien=id 
The decree was principally aimed at consumer and electronic goods but can also be applied to clothing and textiles.

- The impact of the requirement would very much depend on whether 1) consumers would be able or willing to make the repair or 2) whether they would be likely to take their broken garments to a professional repairer.

- Requirement on repair instructions would be an important supplement to this requirement (see requirement 5).

- Provision of additional buttons and thread could also be part of the requirement. This may eventually lead to waste of these of there was no use for them but this would be a small waste compared to the waste if a shirt was disposed of because it missed a button. Many brands already provide spare buttons with shirts, jackets etc.

\begin{tabular}{|c|c|c|c|c|}
\hline \multicolumn{5}{|l|}{ 4. Design for disassembly } \\
\hline \multirow[b]{2}{*}{$\begin{array}{l}\text { Requirement: } \\
\text { The product logo, buttons and zips should be } \\
\text { removable within } X \text { seconds. Seams should } \\
\text { be disassembled within } X \text { seconds but } \\
\text { without reducing durability under normal use } \\
\text { and care. Instructions should be provided on } \\
\text { how to do this }\end{array}$} & \multirow{2}{*}{$\begin{array}{l}\text { Relevant product types: } \\
\text { Garments \& home textiles } \\
\text { made from a range of } \\
\text { materials. Uniforms with } \\
\text { logos }\end{array}$} & \multicolumn{3}{|c|}{ Type of requirement: } \\
\hline & & \multirow[t]{2}{*}{ Informative } & \multirow[t]{2}{*}{ Threshold } & \multirow[t]{2}{*}{ Other } \\
\hline $\begin{array}{l}\text { Broad theme addressed: } \\
\text { Durability } \\
\text { Reparability } \\
\text { Reusability } \\
\text { Recyclability }\end{array}$ & $\begin{array}{l}\text { Testing/documentation } \\
\text { options: } \\
\text { Standard for speed of } \\
\text { disassembly would be } \\
\text { difficult as may need to be } \\
\text { manual test }\end{array}$ & & & \\
\hline
\end{tabular}

\section{Rationale}

Allowing easy disassembly of a product into components including de-logoing can assist consumers and professional repairers to make a repair, and can assist recyclers and/or second-hand organisations in preparing for recycling (total disassembly) or preparing for resale (by removing logos). Logos can be an obstacle to reuse of uniforms.

\section{Comments on scope, challenges and conflicts}

- Techniques, technologies for easy disassembly have potential for reducing strength of removable seams under grab tests etc. This conflict must be avoided through use of innovative technology i.e. seams that melt when exposed to microwaves ${ }^{18}$ etc.

- The requirement would need to be supplemented by a requirement on provision of Information on how to dissemble.

This requirement will entail challenges with regards to children's safety (i.e., choking hazard) and a need to take into account safety regulation in this specific product sector.

\footnotetext{
${ }^{18}$ See for example http://www.ctechinnovation.com/funded-projects/wear2-microwave-textile-disassembly/
} 


\begin{tabular}{|c|c|c|c|c|}
\hline \multirow[b]{2}{*}{$\begin{array}{l}\text { Requirement: } \\
\text { The product must include, or link to, a list of } \\
\text { all materials included in the product and at } \\
\text { what level they are pure or mixed with other } \\
\text { materials, and the share they make up by } \\
\text { weight of the product down to a chosen } \\
\text { threshold (e.g. } 1 \% \text { ) } \\
\text { Products that are made from a single } \\
\text { material (with tolerance around } 98 \% \text { ) must } \\
\text { be stamped with a " } 100 \% \text { recyclable" stamp }\end{array}$} & \multirow{2}{*}{$\begin{array}{l}\text { Product type: } \\
\text { Garments \& Home textiles }\end{array}$} & \multicolumn{3}{|c|}{ Type of requirement: } \\
\hline & & $\begin{array}{l}\text { Informative } \\
x\end{array}$ & Threshold & Other \\
\hline $\begin{array}{l}\text { Theme: } \\
\text { Recyclability } \\
\text { Use of recycled content }\end{array}$ & $\begin{array}{l}\text { Testing/documentation } \\
\text { options: }\end{array}$ & & & \\
\hline
\end{tabular}

\section{Rationale}

This requirement addresses a number of issues. Firstly, knowing the material content of a product can be a pre-requisite in enabling optimal recycling. Mono-material garments are more eminently recyclable than products with a mix of materials. Just small amounts of other materials (typically $1-2 \%$ ) can disrupt some recycling processes. ${ }^{19}$ Both mechanical and especially chemical recycling are difficult for mixed fibres and usually this only allows down-cycling to low quality non-woven products. Chemical recycling methods are under development for some mixes e.g. poly-cotton but concentration of chemicals that need to be used for the processes are highly dependent on the precise fibre mix and are also sensitive to presence of other materials (even dyes). The "100\% recyclable" stamp would be an added measure to put focus on mono-material products.

\section{Comments on scope, challenges and conflicts}

- Regulations (EU) No 1007/2011 of the European Parliament and of the Council of 27th September 2011 on textile fibres and related labelling and marking of the fibre composition of textile products. This requires that the textile label includes the fibre composition in $\%$ shares (but not for shares under $10 \%$ or for non-fibre components like buttons and zips). It could potentially be improved to include all materials down to a lower threshold. Can also be combined with info on whether a material is from recycled sources.

- A bill of materials is nothing new to the textile industry since for most garments a bill of materials $(\mathrm{BOM})$ is produced at the design stage to aid in the production process. ${ }^{20}$ However, the difference here is that the BOM would need to give the actual base material of each item or yarn and its share by weigh tin the product.

- This requirement could also integrate the requirement 1 on declaration of recycled content.

- Care needs to be taken on what a " $100 \%$ recyclable" stamp is applied to. Most mono-material textiles would be $100 \%$ recyclable but some mixes may also be. Some definition of technology is necessary - it should be $100 \%$ recyclable under readily available current technology.

- The $100 \%$ recyclable stamp may conflict to a certain extent with technical durability. Cotton/polyester mixes, for example, can be more technically durable than pure cotton. This suggests that the $100 \%$ recyclable stamp would be more applicable to fast fashion and not recommended for textiles where lifetime is generally limited by technical strength rather than change in style or change in fit e.g. bed-linen.

\footnotetext{
${ }^{19}$ E.g. chemical recycling of cotton performed by Re:Newcell: www.renewcell.se
}

${ }^{20} \mathrm{http}: / /$ www.garmentsmerchandising.com/bom-garment-industry/ 
- The suggested provision goes beyond the current legal requirements set forth in 1007/2011, and in one instance constitutes a breach of the regulation: the labelling and marking of textile products must be durable, easily legible, visible and accessible and, in the case of a label, securely attached. This would rule out linking to some of the information proposed in the provision - unless the regulation was to be changed.

\begin{tabular}{|c|c|c|c|c|}
\hline \multirow{2}{*}{$\begin{array}{l}\text { Requirement: } \\
\text { The product must be accompanied with } \\
\text { information (or link to information) on } \\
\text { recommended care and maintenance } \\
\text { tips that can prolong the lifetime of the } \\
\text { product (and reduce use phase impacts) }\end{array}$} & \multirow{2}{*}{$\begin{array}{l}\text { Relevant product type: } \\
\text { All garments \& } \\
\text { home textiles }\end{array}$} & \multicolumn{3}{|c|}{ Type of requirement: } \\
\hline & & \multirow[t]{2}{*}{$\begin{array}{l}\text { Informative } \\
\mathrm{x}\end{array}$} & \multirow[t]{2}{*}{ Threshold } & \multirow[t]{2}{*}{ Other } \\
\hline $\begin{array}{l}\text { Broad theme addressed: } \\
\text { Durability } \\
\text { Reparability }\end{array}$ & $\begin{array}{l}\text { Testing/documentation } \\
\text { options: } \\
\text { Standard for care labels } \\
\text { already exist: ISO } \\
3758: 2012^{21}\end{array}$ & & & \\
\hline
\end{tabular}

\section{Rationale}

How a product is cared for can have considerable impact on its technical lifetime. For example by washing at lower temperatures, avoiding tumble-drying, avoiding fabric conditioners, avoiding certain care products, technical (and aesthetic) lifetimes can be extended. Environmental impacts of laundering are simultaneously reduced. Information on how to carry out simple repairs can also extend lifetimes. An added benefit of lower temperature washing may be reduced fibres in wastewater and eventually in the natural environment.

\section{Comments on scope, challenges and conflicts}

- The information could include recommendations on washing temperature, alternative detergents i.e. low temperature detergents, avoidance of fabric conditioners, reduced washing frequency (hanging out in cold weather instead), avoidance of tumble-dryers, repair guides for buttons and zips etc. It could also include broader advice on resource efficiency measures like encouraging reuse, sharing etc.

- H\&M and GINETEX, the International Association for Textile Care Labelling, have developed a CleverCare symbol which is included on product labels. The symbol provides a www address which users can follow to find tips on environmentally advantageous care and maintenance. ${ }^{22}$ This could form the basis for mandatory labels.

- In addition to a www address it might be advantageous to also include a OR code link that can be read by smart phones. The OR code could link to tips that are specifically designed for that garment with its particular fibre mix.

- The regular care label standard developed by GINETEX and ISO (ISO 3758:2012) is regularly reviewed and updated and could be updated to include a CleverCare type symbol and link. It should be noted though that the label is international and the EU may need to negotiate with other countries.

\footnotetext{
${ }^{21}$ https://www.iso.org/obp/ui/\#iso:std:42918:en

${ }^{22}$ See http://www.clevercare.info/en and http://www.ginetex.net/clevercare/recommendation-for-a-clever-care/
} 
- There is a risk that consumers may not make use of the label. Research has found, however, that use of care labels by consumers is high provided that the information is relatively simple. ${ }^{23}$

\section{Dimensional changes during washing and drying}

Requirement:

Between minus $x \%$ and plus $x \%$ for woven

products, and durable non-wovens, other

knitted products

Broad theme addressed:

Durability
Relevant product type:

Fitted garments

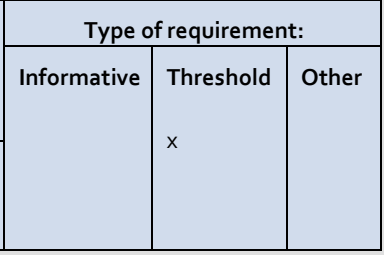

\section{Rationale}

Dimensional change can be one reason for discarding or not using textiles. Laitala et al. (2015) for example found that shape change was the cause of $5 \%$ of clothing disposal cases.

\section{Comments on scope, challenges and conflicts}

- This is a relatively straight-forward requirement since it is already well-used in both ecolabels and in other product standards used, for example, for home textiles.

- The dimensional change could potentially be used as an information declaration instead of a threshold but communication would need to be chosen carefully.

\begin{tabular}{|l|l|l|l|l|}
\hline 9. Colour fastness to washing \\
\hline $\begin{array}{l}\text { Requirement: } \\
\text { Colour-fastness to washing must be at } \\
\text { least X (test score) for colour change and } \\
\text { at least X (test score) for staining }\end{array}$ & $\begin{array}{l}\text { Relevant product type: } \\
\text { Garments \& Home textiles }\end{array}$ & \multicolumn{3}{|c|}{ Type of requirement: } \\
\cline { 2 - 3 } & & Informative & Threshold & Other \\
\hline $\begin{array}{l}\text { Broad theme addressed: } \\
\text { Durability }\end{array}$ & $\begin{array}{l}\text { Testing/documentation } \\
\text { options: } \\
\text { Standard ISO 105 Co6 }\end{array}$ & & & \\
\hline
\end{tabular}

\section{Rationale}

Colour change can be one reason for discarding or not using textiles. Laitala et al. (2015) for example found that colour change and staining was the cause of $11 \%$ of clothing disposal cases and bleeding from other garments for a further $2 \%$.

\section{Comments on scope, challenges and conflicts}

- This is a relatively straight-forward requirement since it is already well-used in both ecolabels and in other product standards used, for example, for home textiles.

23 https://www.researchgate.net/

publication/228295594_Apparel_Care_Labels_Understanding_Consumers\%27_Use_of_Information and

http://www.tandfonline.com/doi/abs/10.1080/00405000008659524?.journalCode=tjti20 
- Threshold could be stricter for dark colours.

- The requirement should exclude white products, products that are neither dyed nor printed, furniture fabrics, curtains or similar textiles intended for interior decoration.

Colour change could potentially be used in an information declaration instead of a threshold but communication would need to be chosen carefully as test results give a simple score which would be hard to translate.

10. Colour fastness to perspiration (acid, alkaline)

Requirement:

Colour fastness must be at least $x$ (test score

for colour change and staining)

Broad theme addressed:

Durability
Relevant product type:

Shirts, t-shirts and blouses

Testing/documentation options: Standard ISO 105 Eo4

\section{Rationale}

Colour change and staining can be one reason for discarding or not using textiles. Laitala et al. (2015) for example found that colour change and staining was responsible in $11 \%$ of clothing disposal cases.

\section{Comments on scope, challenges and conflicts}

- This is a relatively straight-forward requirement since it is already well-used in both ecolabels and in other product standards used, for example, for home textiles.

- Threshold could be stricter for dark colours.

The requirement should be restricted to shirts, $t$-shirts and blouses and other products used close to the skin. They should exclude white products and products that are neither dyed nor printed.

\section{Colour fastness to wet rubbing}

\begin{tabular}{|l|l|l|l|l|}
\hline $\begin{array}{l}\text { Requirement: } \\
\text { Colour fastness to wet rubbing } \\
\text { must be at least X (test score) }\end{array}$ & $\begin{array}{l}\text { Relevant product type: } \\
\text { Garments \& Home textiles }\end{array}$ & \multicolumn{2}{|c|}{ Type of requirement: } \\
\cline { 1 - 2 } $\begin{array}{l}\text { Broad theme addressed: } \\
\text { Durability }\end{array}$ & $\begin{array}{l}\text { Testing/documentation options: } \\
\text { Standard ISO } 105 \mathrm{X}_{12}\end{array}$ & Threshold & Other \\
\hline
\end{tabular}

\section{Rationale}

Colour change can be one reason for discarding or not using textiles. Laitala et al. (2015) for example found that colour change was responsible in $5 \%$ of clothing disposal cases and bleeding from other garments for $2 \%$ of disposal cases.

\section{Comments on scope, challenges and conflicts}

- This is a relatively straight-forward requirement since it is already well-used in both ecolabels and in other product standards used, for example, for home textiles.

- Threshold could be stricter for dark colours. 
- The requirement should exclude white products and products that are neither dyed nor printed.

Acceptability might be limited for some items such as jeans which are intended to fade as part of their aesthetic quality.

\begin{tabular}{|l|l|l|l|l|}
\hline 12. Colour fastness to dry rubbing \\
\hline $\begin{array}{l}\text { Requirement: } \\
\begin{array}{l}\text { Colour fastness to dry rubbing must } \\
\text { be at least X (test score) }\end{array}\end{array}$ & $\begin{array}{l}\text { Relevant product type: } \\
\text { Garments \& Home textiles }\end{array}$ & Informative & Threshold & Other \\
\hline $\begin{array}{l}\text { Broad theme addressed: } \\
\text { Durability }\end{array}$ & $\begin{array}{l}\text { Testing/documentation options: } \\
\text { Standard ISO } 105 \mathrm{~B} 02\end{array}$ & $\times$ & \\
\hline
\end{tabular}

\section{Rationale}

Colour change can be one reason for discarding or not using textiles. Laitala et al. (2015) for example found that colour change was responsible in $5 \%$ of clothing disposal cases. Strict thresholds on for example jeans could also protect sofas from staining, thereby indiretly contributing to a longer sofa-life.

\section{Comments on scope, challenges and conflicts}

- This is a relatively straight-forward requirement since it is already well-used in both ecolabels and in other product standards used, for example, for home textiles.

- Threshold could be stricter for dark colours and in particular for indigo-dyed denim. However, here there could be a potential conflict with aesthetics. Acceptability might be limited for some items such as jeans which are intended to fade as part of their aesthetic quality.

The requirement should exclude white products and products that are neither dyed nor printed.

\begin{tabular}{|l|l|l|l|l|}
\hline \multicolumn{2}{|l|}{ 13. Colour fastness to light } \\
\hline $\begin{array}{l}\text { Requirement: } \\
\text { Colour fastness to light must be } \\
\text { at least X (test score) }\end{array}$ & $\begin{array}{l}\text { Relevant product type: } \\
\text { Garments \& Home textiles }\end{array}$ & \multicolumn{3}{|c|}{ Type of requirement: } \\
\cline { 2 - 2 } $\begin{array}{l}\text { Broad theme addressed: } \\
\text { Durability }\end{array}$ & $\begin{array}{l}\text { Testing/documentation options: } \\
\text { Standard ISO } 105 \text { Bo2 }\end{array}$ & & Threshold & Other \\
\hline
\end{tabular}

\section{Rationale}

Colour change can be one reason for discarding or not using textiles. Laitala et al. (2015) for example found that colour change was responsible in $5 \%$ of clothing disposal cases.

\section{Comments on scope, challenges and conflicts}

- This is a relatively straight-forward requirement since it is already well-used in both ecolabels and in other product standards used, for example, for home textiles.

- Threshold could be stricter for dark colours and in particular for indigo-dyed denim. However, here there could be a potential conflict with aesthetics. Acceptability might be limited for some items such as jeans which are intended to fade as part of their aesthetic quality.

The requirement should exclude white products and products that are neither dyed nor printed. 


\section{Fabric resistance to pilling and abrasion}

\begin{tabular}{|c|c|c|c|c|}
\hline Requirement: & Relevant product type: & \multicolumn{3}{|c|}{ Type of requirement: } \\
\hline $\begin{array}{l}\text { Fabrics shall resist pilling of a } \\
\text { minimum of at least } X \text { (test score) }\end{array}$ & Garments \& Home textiles & \multirow[t]{2}{*}{ Informative } & Threshold & Other \\
\hline $\begin{array}{l}\text { Broad theme addressed: } \\
\text { Durability }\end{array}$ & $\begin{array}{l}\text { Testing/documentation } \\
\text { options: } \\
\text { ISO 12945-1:2000(en) ISO 12945- } \\
\text { 2:2000(en) }\end{array}$ & & $x$ & \\
\hline
\end{tabular}

\section{Rationale}

Pilling and abrasion can be one reason for discarding or not using textiles. Laitala et al. (2015) for example found that pilling was responsible in $3 \%$ of clothing disposal cases with a worn out look responsible for a further $7 \%$.

\section{Comments on scope, challenges and conflicts}

- This is a relatively straight-forward requirement since it is already well-used in both ecolabels and in other product standards used, for example, for home textiles.

- Most applicable to knitwear and other wool/acrylic garments but also bed-linen, stockings, socks etc.

The requirement can be differentiated depending on product types as following: Non-woven fabrics and knitted garments, accessories and blankets made of wool, wool blends and polyester (including fleece), shall resist pilling of a minimum of $X$. Woven cotton fabrics used for garments shall resist pilling of a minimum of $X$. Polyamide tights and leggings shall resist to a rating of a minimum of $X$.

\begin{tabular}{|c|c|c|c|c|}
\hline \multirow{2}{*}{$\begin{array}{l}\text { Requirement: } \\
\text { The total content of organic } \\
\text { fluorine must not exceed } X \mu \mathrm{g} F-/ \mathrm{g} \\
\text { garment }\end{array}$} & \multirow{2}{*}{$\begin{array}{l}\text { Relevant product type: } \\
\text { Garments }\end{array}$} & \multicolumn{3}{|c|}{ Type of requirement: } \\
\hline & & Informative & Threshold & Other \\
\hline $\begin{array}{l}\text { Theme: } \\
\text { Recyclability }\end{array}$ & $\begin{array}{l}\text { Testing/document action } \\
\text { options: } \\
\text { Combustion lon Chromatography } \\
\text { of fluoride (CIC-F) }\end{array}$ & & $\mathrm{X}$ & \\
\hline
\end{tabular}

\section{Rationale}

Impregnation agents based on polyfluoroalkyl substances (PFAS) are widely used in outdoor textiles in order to achieve water, oil and dirt repellence of the fabric, while at the same time maintaining breathability. However, these substances can have negative effects on human health. Under fibre-tofibre recycling processes there is a risk of cross-contamination of PFAS into textiles not aimed for outdoor use, unnecessarily increasing human exposure. They also raise a potential occupational health risk for recycling staff. Especially for applications where repellence against oil, alcohol and oil-based dirt is not required, alternative impregnation agents provide acceptable properties at similar cost.

\section{Comments on scope, challenges and conflicts}

- Outdoor textiles and work clothing, except where the manufacturer can justify a specific need for efficient repellence of oil, alcohol and oil-based dirt. 
- In addition to repellence of water, oil and dirt, the PFAS-based impregnation agents provide repellence to alcohol and a high level of washing and dry cleaning durability. The PFAS increase the user value and the durability of the textiles and there are presently limited options for substituting PFAS with another substance providing repellence to oil and dirt.

The knowledge of most PFAS is limited in terms of usage and possible environmental and health impacts. A main concern regarding the PFAS-based impregnating agents is the formation and release of persistent PFAS or precursors for persistent PFAS, but also potential occupational health risk for recycling staff is a concern. Based on a precautionary principle a threshold is suggested. 


\section{Potential environmental benefits of the proposed requirements for textiles}

The environmental impacts of a specific textile product can be calculated via a detailed life cycle assessment (LCA) of all the processes involved in the production, use stage and disposal of that product. Such an LCA is a large piece of work, involving significant data collection efforts, site visits, modelling and gap filling via carefully selected assumptions.

The requirements proposed for textiles in Chapter 5 would potentially affect thousands of different product types, from many different fibres, produced by thousands of different companies under countless different conditions. There are over 430 different product groups identified under garments and home textiles under the 8-digit $\mathrm{CN}$ product code system and under each of these there can be hundreds of different products types or classes being produced.

Moreover, the requirements we have proposed show the types and formulation of requirements that can be used rather than specifying specific thresholds. In keeping with how the Ecodesign Directive has been implemented to date, negotiated thresholds and/or scope of product covered by each criterion would in all likelihood develop over time, with increasing environmental savings.

This assessment presents considerations that should be taken when making an environmental evaluation of a given requirement and then present some rough means of estimating the relative potential impact of each criterion.

\subsection{Three routes towards environmental savings}

There are three broad routes via which the various proposed requirements can lead to reductions in impacts caused over the lifecycle of textiles consumed in the EU. Each criterion has the potential to reduce environmental pressures via one or more of these routes:

A. Extending the lifetime of products - extending lifetimes of products should reduce the consumption and thereby the production of new textiles. This will reduce the environmental impacts associated with the full production phase of the offset textile products.

B. Replacement of virgin materials with recycled materials - will reduce the environmental impacts associated with the production of the virgin material. 
Though it will not offset environmental impacts caused during subsequent processing. For example, replacing virgin cotton with recycled cotton offsets impacts caused by growing, harvesting and ginning of cotton, but not with spinning, weaving, dyeing and finishing of the final cotton product. The savings are also partially offset by the environmental impacts caused by recycling processes.

C. Altering laundry processes/habits - has the potential to reduce the environmental impacts of laundering. This could be via reductions in washing temperatures which would reduce energy use, or via reducing frequency of washes which would reduce energy, water and detergent use.

\subsection{From eco-design requirements to environmental savings}

The requirements have varying impacts on each of these three main routes. Firstly, there will be varying strengths of links between the requirements and the route. For example, a minimum threshold set for the recycled content in all cotton products at $5 \%$, is likely to lead to a $5 \%$ or higher replacement of virgin cotton used in textiles consumed on the European market i.e. a strong connection between requirement and result.

On the other hand a declaration requirement on importers/ producers to state how much recycled content there is in cotton products is reliant upon consumers actively choosing recycled content and could be expected to lead to a lower replacement rate of virgin cotton by recycled cotton.

Secondly, the total impact of a requirement will depend upon the potential scope of textiles that will be affected. A requirement concerning for example the durability of zippers will only affect the life expectancy of the share of total consumed textiles that have zippers. A requirement concerning the tensile strength of fibres can potentially affect the life expectancy of all textile products.

The magnitude of environmental savings for a given environmental impact category can roughly be described by the following:

- Environmental savings = Environmental footprint (of all consumed textiles) $x$

Potential percentage reductions for a given route $x$ Strength of link between a requirement and route $x$ Share of total textiles affected.

\subsection{Relative reductions in impacts for a given route}

For a given quantity of textiles, each of the three routes described earlier will give widely varying environmental savings depending on, for example, what the product is made from, where it was produced and how (Route A), what type of virgin material is replaced and under what processes (Route B), how laundry processes are altered and in which country and with which equipment (Route $C$ ). 
JRC (2014) modelled both total impacts of the lifecycle of textiles consumed in the $\mathrm{EU}$ and the potential savings that could be gained via various improvements when averaged across all fibre types and product types. Some of the improvements are not relevant here and concern farming methods, dyeing methods and so on. Others are directly relevant to the three routes.

Figure 2: The share of total lifecycle impacts of textiles consumed in the EU across 18 different impact categories, split between lifecycle phases

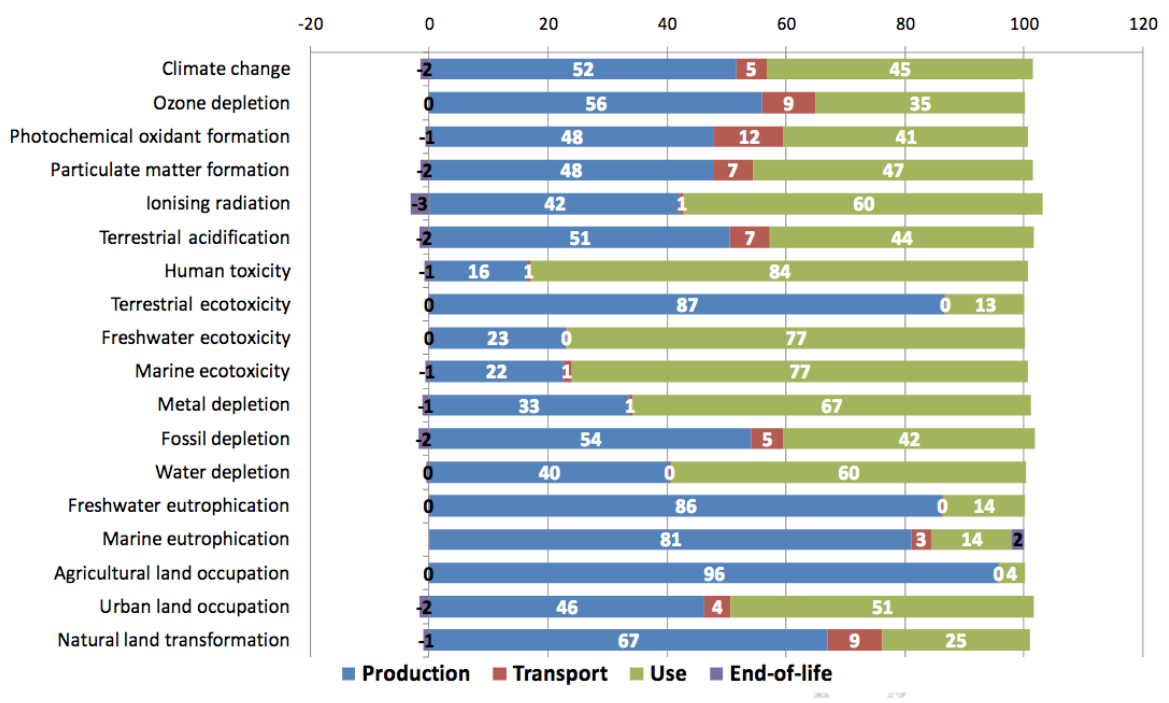

Source: JRC, 2014 .

With relevance to the three routes we are concerned with, JRC (2014) modelled various potential changes in laundry habits (our Route $C$ ) that could conceivably be encouraged across the $\mathrm{EU}$, and in potential increases in collection of used textiles and subsequent reuse (i.e. extending lifetimes; our Route A) and in recycling (replacement of virgin materials; our Route B).

One issue to note before presenting the results of the scenario modelling is that they vary significantly between different impact categories. Figure 3 partially illustrates this by providing an overview of the share of lifecycle impacts between lifecycle stages.

In Table 4 below we present the results of JRC's modelling for just three impact categories; climate change, water depletion and terrestrial acidification. We also present the scenarios that were modelled in each case. 
Table 4: Relevant scenarios modelled by JRC

\begin{tabular}{ll|cc}
$\begin{array}{l}\text { Relevance to } \\
\text { which route }\end{array}$ & Scenario modelled & $\begin{array}{r}\text { Percentage reduction in total lifecycle } \\
\text { impacts of textiles }\end{array}$ & $\begin{array}{c}\text { Human } \\
\text { Climate } \\
\text { change } \\
\text { toxicity }\end{array}$ \\
depletion
\end{tabular}

The scenarios were JRC's best guesses at what would be possible to encourage in the medium term across the EU as a whole based on the 2012 baseline, and using bestperforming countries as a benchmark. They include many assumptions many of which would now need to be adjusted for current baseline conditions such as the average energy efficiency of washing machines, market penetration of tumble driers and used textile reuse and recycle rates etc.

The first three scenarios provide a reasonable starting point for estimates of Ecodesign requirements that impact via Route $C$. Care information provided on/via textile products could include recommendations/guidance/nudging on wash temperature, airdrying and optimising machine loads. The potential changes encouraged seem like a reasonable upper level.

Route $A$, however, is only partially represented by the final scenario. Route $A$ concerns extending the active lifetime of all textiles, not just those that are separately collected and sold for reuse, but also extended lifetimes by the original user. Many of the eco-design requirements concern repair, increase in quality/durability and other means for encouraging the original user to wait longer before discarding. In addition, increased durability/reparability will also mean that the garment can have a longer second life following collection and (most often) export for reuse. JRC (2014) assumed that reuse would extend a garment's lifetime by $50 \%$ - increased quality could extend this further

On the other hand, none of the eco-design requirements would directly increase collection rates of discarded textiles. As assumed by JRC, increasing collection rates is the most sure way of extending textile lifetimes. The ecodesign requirements can indirectly increase collection rates by 1 ) increasing textile quality and 2) recyclability to higher value products. Both would increase the economic value of discarded textiles and encourage collectors to make additional effort to increase collection.

Nevertheless, the JRC modelled scenario seems rather optimistic. A 70\% collection rate is very high for EU as a whole, exceeding even the best performing countries today. This will only be achieved if the economics of collection improves significantly and if 
concerted effort is made at EU and national level to increase collection. The coming revised Circular Economy Package looks likely to include requirements for Member States to ensure effective separate collection systems.

A further complicating factor is that Route $B$ is included along with Route $A$ in a single scenario. If we would wish to split the savings of Routes $A$ and $B$ we would find that Route A would dominate the savings. Schmidt et al. (2016) found that extending the lifetime of a textile product (via reuse) would give between 6 and 50 times the climate benefits compared to recycling the same product, depending on the fibre type and the recycling process.

The benefits of reuse calculated by Schmidt et al. (2016) assumed a 1:1 offsetting of new products i.e. for each second-hand shirt sold one less new shirt would be produced. Even with a more conservative replacement rate of around $30 \%$ that has been estimated in the UK, the benefits were still more than double those of recycling the same garment. Moreover, the share of collected textiles that are reused and recycled is skewed in JRC's sample. Watson et al. (2016) for example finds that, of used textiles collected in Nordic countries, roughly $65 \%$ is reused and $25 \%$ is recycled. Thus increasing collection rates may give greater absolute increases in reuse than recycling.

Finally Route $B$ savings as encouraged by ecodesign requirements might be higher than predicted under the JRC scenario, since ease of recyclability requirements are intended to encourage textile-to-textile recycling rather than down-cycling. This tends to give greater benefits. The JRC scenario assumed that all recycling would be into industry wipes, replacing paper towels.

All in all, we are satisfied with JRC's scenarios as an upper limit for Route C savings that could potentially be achieved via ecodesign requirements but feel that a somewhat higher potential could be set for Routes A and B.

UK WRAP (2012) found that extending the average lifetime of clothing by just three months of active use would reduce environmental footprints of textiles by $5-10 \%$. 3 months is a conservative increase in active lifetimes given that active lifetime of clothing currently range between 3 and 5 years depending on the type of clothing (UK WRAP, 2015).

We set the ceiling here for savings across the lifecycle of textiles consumed in the EU for climate change at $8 \%$ for Route A, 4\% for Route B and $10 \%$ for Route C. Since JRC (2012) estimated the total global lifecycle GHG emissions of textiles consumed in the $\mathrm{EU}$ as being 413 million tonnes $\mathrm{CO}_{2}$-equiv., this could combined give savings of up to 85 million tonnes $\mathrm{CO}_{2}$-equiv.

\subsection{Strength of link between requirements and saving routes}

For each requirement the size of environmental savings will depend on a number of factors; the strength of causal links between the requirement, the response of the industry/consumer to the requirement and eventual environmental savings; and the total weight of textile products that will be affected by the given requirement. These factors are discussed in Table 5 . 
Table 5: Links between ecodesign requirement and eventual environmental savings

\begin{tabular}{l|lll} 
Requirement & $\begin{array}{l}\text { Route to } \\
\text { environmental } \\
\text { savings }\end{array}$ & $\begin{array}{l}\text { Strength of links between requirement } \\
\text { and environmental savings }\end{array}$ & $\begin{array}{l}\text { Potential share of textiles } \\
\text { affected }\end{array}$
\end{tabular}

1. Declaration of and/or minimum threshold for recycled materials
B. Replacement of

B. Replacement
virgin material
Minimum threshold $>>$ High strength link provided that the threshold is well policed and documented using 3 rd party certificate. Magnitude of impact depends on threshold set. Low for cotton, higher for polyester.

Declaration >> Low/medium strength link though depends on how the label is communicated. A Defra report ${ }^{24}$ found that share of population who always or often responded to a label varied from $3 \%$ to almost 60\%. 60\% was achieved for energy labels under the Eco-Design Directive and was far above response rate for any other label: here there is a clear economic incentive for consumers. A further study 25 found that between 18 to $31 \%$ of Europeans claimed to strongly or moderately take environmental considerations into account when purchasing textiles.

High strength link for products with zippers since these are often the first thing to fail on coats, cardigans etc. and repair is difficult i.e. if a zipper fails the product may often be discarded. We do not know the failure rate for average zippers but high quality certified zippers from YKK represent nearly half the market. ${ }^{26}$

Medium strength link for products with buttons since buttons can easily be repaired. However, only if a replacement button can be found.

The degree to which both extend technical lifetimes depends on the level of the minimum threshold.

Medium strength $-35 \%$ of Norwegians often make their own repairs of clothing ${ }^{27}$ while $19 \%$ of Britons could use over half their unworn clothes if they were repaired. ${ }^{28}$ Most people (74\%) can sew on a button if they had one available though only $24 \%$ could replace a zip. ${ }^{29}$
Medium - In first phase may limit to products for which recycled content is readily available.

High - if labelling is requires on all clothing and household textiles.
Low/Medium - In Denmark approximately $45 \%$ of the total weight of textiles are coats, shirts/blouses, and cardigans/sweaters. Perhaps half of this weight includes fasteners though product statistics do not allow this figure to be deduced.
High - would cover all textile products though those with buttons and other fasteners represent perhaps $20 \%$.

\footnotetext{
24 Brook Lyndhurst and Icaro Consulting (2011).

25 http://www.global-standard.org/media/com_acymailing/upload/ecolabels_2013_paper_es_194.pdf

${ }^{26} \mathrm{https} / / / \mathrm{www}$. forbes.com/global/2003/1124/089.html

27 Laitala and Boks (2012).

28 UK WRAP (2012b).

29 UK WRAP (2012b).
} 


\begin{tabular}{|c|c|c|c|}
\hline Requirement & $\begin{array}{l}\text { Route to } \\
\text { environmental } \\
\text { savings }\end{array}$ & $\begin{array}{l}\text { Strength of links between requirement } \\
\text { and environmental savings }\end{array}$ & $\begin{array}{l}\text { Potential share of textiles } \\
\text { affected }\end{array}$ \\
\hline \multirow[t]{2}{*}{$\begin{array}{l}\text { 4. Design for } \\
\text { disassembly and } \\
\text { 5. Repair and } \\
\text { disassembly } \\
\text { instructions }\end{array}$} & $\begin{array}{l}\text { A. Extending the } \\
\text { lifetime of } \\
\text { products }\end{array}$ & $\begin{array}{l}\text { Medium strength - This could assist in } \\
\text { repairing the } 35 \% \text { to } 65 \% \text { of clothing that is } \\
\text { discarded due to technical failures. } 3^{\circ} 35 \% \text { of } \\
\text { Norwegians often make their own repairs of } \\
\text { clothing } 3^{11} \text { while } 19 \% \text { of Britons could use } \\
\text { over half their unworn clothes if they were } \\
\text { repaired. Most people ( } 74 \% \text { ) are already able } \\
\text { to sew on a button, and nearly half can darn } \\
\text { or patch a hole, and adjust a hem ( } 47 \%) \text { but } \\
\text { less than a quarter can mend a broken zip, } \\
\text { replace a pocket or adjust a size. } 3^{32}\end{array}$ & $\begin{array}{l}\text { High - would potentially } \\
\text { cover all textile products. }\end{array}$ \\
\hline & $\begin{array}{l}\text { B. Replacement of } \\
\text { virgin material }\end{array}$ & $\begin{array}{l}\text { Low strength - is questionable whether it } \\
\text { would make economic sense under current } \\
\text { process for recycled materials for recyclers } \\
\text { to make the effort to dissemble clothing for } \\
\text { material recycling. }\end{array}$ & $\begin{array}{l}\text { Low - only relevant for } \\
\text { textiles with fasteners or } \\
\text { logos that need removal. }\end{array}$ \\
\hline $\begin{array}{l}\text { 6. Provision of } \\
\text { detailed bill of } \\
\text { materials and } \\
100 \% \text { recyclability } \\
\text { stamp }\end{array}$ & $\begin{array}{l}\text { B. Replacement of } \\
\text { virgin material }\end{array}$ & $\begin{array}{l}\text { Low/Medium strength - this requirement will } \\
\text { not increase the degree of recyclable waste } \\
\text { textiles but will simply make information on } \\
\text { fibre composition available to recyclers. } \\
\text { Under current economic and technical } \\
\text { conditions it would make little economic } \\
\text { sense for a manual sorter to check labels. } \\
\text { However, in the future as automatic sorters } \\
\text { become more standard, readable labels such } \\
\text { as RFIDs could significantly increase sorting } \\
\text { efficiencies. Moreover as recycling } \\
\text { technologies improve and this will allow a } \\
\text { greater degree of fibre mixes to be recycled } \\
\text { giving more impact to this requirement. }\end{array}$ & $\begin{array}{l}\text { High - would cover all textile } \\
\text { products. }\end{array}$ \\
\hline \multirow[t]{2}{*}{$\begin{array}{l}\text { 7. Care and } \\
\text { maintenance } \\
\text { labelling }\end{array}$} & $\begin{array}{l}\text { A. Extending the } \\
\text { lifetime of } \\
\text { products }\end{array}$ & $\begin{array}{l}\text { Medium strength -consumers are relatively } \\
\text { responsive to care labels. The strength } \\
\text { between laundering and longer life is less } \\
\text { strong: According to UK WRAP ( } 2012 \mathrm{~b} \text { ) } \\
\text { only } 10 \% \text { of consumers have discarded } \\
\text { clothing because of fading, stains and } \\
\text { garments losing their shape in the laundry }\end{array}$ & $\begin{array}{l}\text { High - all textiles and } \\
\text { clothing would be affected. }\end{array}$ \\
\hline & $\begin{array}{l}\text { C. Altering laundry } \\
\text { processes/habits }\end{array}$ & $\begin{array}{l}\text { High strength - According to WRAP (2012) } \\
\text { research consumers are relatively } \\
\text { responsive to care labels. Around } 60 \% \\
\text { already wash at } 30^{\circ} \mathrm{C} \text { or less at least half } \\
\text { the time and } 40 \% \text { would seriously consider } \\
\text { using clothing a greater number of times } \\
\text { before laundering. }\end{array}$ & As above. \\
\hline $\begin{array}{l}\text { 8.-14. } \\
\text { Dimensional } \\
\text { changes, colour } \\
\text { fastness and } \\
\text { fabric resistance } \\
\text { requirements }\end{array}$ & $\begin{array}{l}\text { A. Extending the } \\
\text { lifetime of } \\
\text { products }\end{array}$ & $\begin{array}{l}\text { Low/Medium strength -according to WRAP } \\
\text { ( } 2012 \text { ) only } 10 \% \text { of clothing discards are } \\
\text { caused by dimensional changes and } \\
\text { changes in colour. Laitala et al. (2015) } \\
\text { found this to be approximately } 15 \% \text {. }\end{array}$ & $\begin{array}{l}\text { Medium/High - can } \\
\text { potentially be required for all } \\
\text { clothing and home textiles but } \\
\text { in first wave would perhaps } \\
\text { only require for basic clothing } \\
\text { (T-shirts, underwear, jeans) } \\
\text { and home textiles. }\end{array}$ \\
\hline
\end{tabular}

\footnotetext{
$3^{\circ}$ Laitala (2014).

${ }^{31}$ Laitala and Boks (2012).

32 UK WRAP (2012b).
} 


\section{Potential eco-design requirements for furniture}

Furniture is a broad product group that encompasses very different types of furniture (chairs, tables, wardrobes, shelves, cupboards etc.) with very different uses (for schools, offices, kitchens, bathrooms, outdoors, special uses, etc.).

Furniture comprise free-standing or built-in units whose primary function is to be used for the storage, placement or hanging of items and/or to provide surfaces where users can rest, sit, eat, study or work, whether for indoor or outdoor use. The scope extends to domestic furniture and office furniture items for use in domestic or nondomestic environments.

According to the Swedish furniture industry 33 the average Swedish furniture product consists, by weight, of $70 \%$ wood (-based material), $15 \%$ padding materials (mainly polyurethane and polyester foam), 10\% metals and $5 \%$ other materials (plastics, textiles, glass, etc.). Combining this with the share by value, the most used materials used in furniture are:

- wood and wood-based panels

- metals

- plastics

- textiles and

- foam materials.

In general, the environmental impact of furniture stems mostly from the production and treatment of the raw materials used in manufacturing, rather than from the production of the furniture itself (EC, 2008).

As agreed with the NCM, the consultant has carried out a "light application" of the methodology described in Chapter 2 as applied to furniture. It should be noted, that the following draft requirements are based on process of short duration and with only minor consultation with industry/ stakeholders. ${ }^{34}$ As such, the draft criteria should only be seen as an initial effort to apply the described methodology to other product areas.

33 Dr. Jürgen Bärsch: The feasibility of an EU eco-label for furniture, (2001).

34 We received comment/input from Ellen Hoog Antink from the Circular Economy department of Dutch Rijkswaterstaat. 
Table 6: First proposals for ecodesign requirements for furniture

\section{No Potential requirement \\ Comment}

\section{$1 \quad$ Fitness for use}

Furniture shall be considered as fit for use if it complies with the requirements set out in the latest versions of any relevant $X$ standards that relate to the durability, dimensional requirements, safety and strength of the product.

\section{$2 \quad$ Expected lifespan}

Product manufacturer must inform/declare the expected lifespan of the product by normal use.

\section{Provision of spare parts}

The furniture manufacturer shall make spare parts available to customers for a period of at least $X$ years from the date of delivery of the product. The cost (if any) of spare parts shall be proportional to the total cost of the furniture product.

\section{$4 \quad$ Design for disassembly}

For furniture consisting of multiple component parts/materials, the product shall be designed for disassembly with a view to facilitating repair, reuse and recycling. Simple and illustrated instructions regarding the disassembly and replacement of damaged components/ parts/materials shall be provided. Disassembly and replacement operations shall be capable of being carried out using common and basic manual tools and unskilled labour.

\section{Consumer information/instructions}

The consumer shall be provided with i) a detailed description of the best ways to dispose of the product (i.e. reuse, take-back initiative by the producer, recycling, energy recovery); ii) Guidance on cleaning and maintaining the product; iii) Assembly and disassembly instructions.

\section{$7 \quad$ Bill of materials}

Producers must provide an overall bill of materials stating the total weight of the product unit, how the weight is split among different materials, and placement of different components. Plastics must be defined by type and physically marked. Recycled materials must also be declared.

\section{$9 \quad$ Packaging materials}

Packaging must consist of readily recycled material and/or materials taken from renewable resources or be a multi-use system.
This requirement can relate to standards on, as example, durability and quality of the product. Today there is no requirements on furniture apart from consumer law. Third part verified/developed standards can secure a continuous improvement raising the bottom level. ISO standards normally correspond to around 5-10 years of use.

Information on the expected lifespan of the product can inform the consumer of the quality of the product and also serve as a precursor to a requirement on prolonged warranty. The present standards that address durability simulate 5-10 years real life usage. Some companies have their own testing equipment and may run longer cycles (tests) to find out maximum durability - such data is seldom publicly available.

Making spare parts available can enable repair and with this a longer life of the product.

Design for disassembly is essential in enabling repair and recycling since many products on the market today are difficult to separate into different materials for recycling or to repair. The producer shall provide technical drawings that illustrate how the furniture item can be assembled/disassembled using basic tools and unskilled labour.

There is a potential conflict between disassembly and durability/expected lifetime since joints with bolts and screws tend to be more prone to fatigue and loosening with time than fixed joints.

In order to ensure a longer active life of the product guidance on maintenance shall be provided to the consumer, furthermore the consumer should be encouraged to reuse etc. if comprehensive instead of disposal.

A bill of materials will provide the user information on the recyclable materials in the product and with this motivate the user to increased recycling.

Information on the contents of recycled materials could increase the use of such materials (in order to meet consumer demands).

Information criterion criteria to allow industry to adapt and invest with a long term perspective.

Definition of plastic parts and recycled parts will ease recycling.

Furniture is typically wrapped in considerable amounts of packaging to protect the product during transportation. There are considerable environmental perspectives in increasing the use of recycled/renewable packaging materials. 


\section{Conclusion}

European Commission working groups are currently developing standards for ecodesign requirements for energy-related products that address material efficiency. There are however, significant material efficiency gains to be made if these types of requirements were applied to non-energy related products.

Textiles and furniture are two examples of non-energy related products for which application of ecodesign can give considerable benefits.

The project has shown that it is possible to formulate relevant both quantitative and qualitative ecodesign criteria for non-energy related product groups using the described methodology:

- Setting a cross-disciplinary team.

- Defining the scope for textiles.

- Literature review and internal workshop.

- First draft requirements.

- Stakeholder consultation.

- Preparation of final ecodesign requirements.

The litmus test of the criteria will be a more thorough market dialogue uncovering the sector's ability to comply with the specific criteria in immediate and longer term. Determining ambitious but feasible thresholds for many of the criteria requires both this intensive consultation and not least a political process during which the strictness of future ecodesign criteria for textiles can be decided in the light of other important parameters and prioritisations. 


\section{References}

Ardente, F., Mathieux, F. and Sanfélix Forne, J. (2012) Integration of resource efficiency and waste management criteria in European product policies: Analysis of Durability. Joint Research Council Technical Report EUR 25656 EN.

Brook Lyndhurst and Icaro Consulting (2011) Consumer understanding of green terms. A research report completed for the Department for Environment, Food and Rural Affairs by Brook Lyndhurst and Icaro Consulting.

Bundgaard, A., Remmen, A. and Overgaard Zacho, K. (2015) ecodesign directive version 2.0 From Energy Efficiency to Resource Efficiency. Danish EPA Environmental project No. 1635, 2.

Dalhammar, C., Machacek, E., Bundgaard, A., Overgaard Zacho, K. and Remmen, A. (2014) Addressing resource efficiency through the ecodesign directive. TN2014:511. Nordic Council of Ministers. https://doi.org/10.6027/TN2014-511

Elander, M. and Ljungkvist, H. (2016) Critical aspects in design for fiber-to-fiber recycling of textiles. Mistra Future Fashion report 2016:1.

Elander, M, Watson, D. and Gylling, A.C. (2017) Evaluation of business models for increased reuse, collective use and prolonged life-time of textiles. Report under the Mistra Future Fashion Program Phase II.

European Commission (2014) Decision of 5 June 2014 establishing the ecological criteria for the award of the EU Ecolabel for textile products. 2014/350/EU.

European Commission (2015a) Closing the loop - An EU action plan for the Circular Economy. Communication from the Commission COM/2015/0614 Final.

European Commission (2015b) Commission Implementing Decision of 17.12.2015 on a Standardisation Request to the European Standardisation Organisations. C(2015) 9096 Final.

European Commission (2017) EU green public procurement criteria for textiles products and service. Commission Staff Working Document SWD(2017) 231 final, Brussels, 6.6.2017.

European Commission: Regulation No 1007/2011 of the European Parliament and of the Council of 27 September 2011 on textile fibre names and related labelling and marking of the fibre composition of textile products and repealing Council Directive 73/44/EEC and Directives 96/73/EC and 2008/121/EC of the European Parliament and of the Council Text with EEA relevance.

European Commission: DIRECTIVE 2005/29/EC OF THE EUROPEAN PARLIAMENT AND OF THE COUNCIL of 11 May 2005 concerning unfair business-to-consumer commercial practices in the internal market and amending Council Directive 84/450/EEC, Directives 97/7/EC, 98/27/EC and 2002/65/EC of the European Parliament and of the Council and Regulation (EC) No 2006/2004 of the European Parliament and of the Council "Unfair Commercial Practices Directive".

European Environment Agency EEA (2013) Environmental pressures from European consumption and production. EEA Technical Report No 2/2013.

http://www.eea.europa.eu/publications/environmental-pressures-from-europeanconsumption

Galatola, Michele, DG ENV, EU Commission - slide presentation on product environmental footprint.

German Environment Agency (2017) Obsolescence - Political strategies for improved durability of products.

https://www.umweltbundesamt.de/sites/default/files/medien/376/dokumente/policy_brie f_obsolescence_-_political_strategies_for_improved_durability_of_products.pdf 
Global Organic Textile Standard International Working Group (2014) Global OrganicTextile Standard (GOTS) Version 4.0.

JRC (2014) Environmental Improvement Potential of textiles (IMPRO Textiles). Joint Research Centre Scientific and Policy Reports. European Commission.

Laitala, K. (2014) Consumers' clothing disposal behaviour - a synthesis of research results. International Journal of Consumer Studies 38 (2014) 444-457.

https://doi.org/10.1111/ijcs.12088

Laitala, K., Boks, C., and Grimstad Klepp, I. (2015) Making Clothing Last: A Design Approach for Reducing the Environmental Impacts. International Journal of Design Vol. 9 No. 22015.

Laitala, K. \& Boks, C. (2012) Sustainable Clothing Design: Use matters. Journal of Design Research 10(1/2), 21-139. https://doi.org/10.1504/JDR.2012.046142

Nordic Council of Ministers (2015) Well dressed in a clean environment: Nordic action plan for sustainable fashion and textiles. Nordic Council of Ministers, Copenhagen.

Nordic Ecolabel (2012) Nordic Ecolabelling of textiles, hides/skins and leather. Version 4.7 12 December 2012-31 December 2018.

PLATE (2017) Conference on Product Lifetimes and the Environment (PLATE). Conference proceedings: http://ebooks.iospress.nl/ISBN/978-1-61499-820-4

Schmidt, A., Watson, D., Roos, S., Askham, C. and Brunn Poulsen, P. (2016) Gaining benefits from discarded textiles: LCA of different treatment pathways. TN2016:537. Nordic Council of Ministers. https://doi.org/10.6027/TN2016-537

Swedish Government (2015) Circular Economy - elements for the new proposal. Non-paper 2015-06-26. Retrieved from

http://www.regeringen.se/49e7eg/contentassets/eb811ode24394134920d420fe3obc928/circula r-economy--elements-for-the-new-proposal.pdf

Swedish Society for Nature Conservation (2012) Good Environmental Choice: Textiles Criteria 2012:3.

UK WRAP (2012a) Valuing our clothes. The true cost of how we design, use and dispose of clothing in the UK.

http://www.wrap.org.uk/sites/files/wrap/VoC\%2oFINAL\%20online\%202012\%2007\%2011.pdf

UK WRAP (2012b) Valuing our clothes: the evidence base. Technical Report. http://www.wrap.org.uk/sites/files/wrap/10.7.12\%20VOC-\%2oFINAL.pdf

UK WRAP (2015) Sustainable clothing: A practical guide to enhancing clothing durability and performance.

http://www.wrap.org.uk/sites/files/wrap/WRAP\%20Sustainable\%20Clothing\%20Guide.pdf

Ungerth, L. and Carlsson, A. (2011) Vad Händer Sen Med Våra Kläder? Enkätundersökning (What Is Done with Our Clothes? A Survey). Konsumentföreningen, Stockholm.

Watson, D. and Bundgaard Nielsen, M. (2016) Partnership on a Longer Active Lifetime for Textiles. Pre-study' report for the Danish EPA.

Watson, D., Palm, D., Syversen, F., Brix, L., Amstrup, M. and Nielsen, R. (2016) Exports of Nordic Used Textiles: Fate, Benefits and Impacts. TemaNord report 2016:789. Nordic Council of Ministers. https://doi.org/10.6027/NA2016-905

Watson, D., Elander, M., Gylling, A., Andersson, T. and Heikkilä, P. (2017) Stimulating the Demand for Recycled Textiles. Nordic Council of Ministers TemaNord Report. 


\section{Sammenfatning}

Godt design kan øge ressourceeffektivitet ved at bidrage til at produkter er holdbare og lette at reparere, opgradere og reproducere, samt hvor nyttiggørelse af værdifulde materialer og komponenter gøres muligt ved endt levetid. Ecodesign Direktivet er indtil nu primært blevet anvendt til at forbedre produkters energieffektivitet, men direktivet har et betydeligt potentiale for også at fremme produkters ressourceeffektivitet. EU Kommission har øje for dette potentiale og ser på mulighederne for at udarbejde kriterier for produkters ressourceeffektivitet under direktivet. Denne type kriterier er desuden begyndt at indgå i kriterieudkast til energirelaterede produkter.

Kriterier vedrørende produkters ressourceeffektivitet indebærer en stor potentiel miljøgevinst for bl.a. tekstilprodukter. I tekstilers værdikæde sker en betydelig affaldsdannelse på grund af hurtigt skiftende mode, faldende kvalitet, og relativ lav reparations- og genbrugsrate, og samtidig betyder produkternes korte levetid, at der produceres store mængder nye tekstiler med en betydelig miljøpåvirkning til følge. I det foreliggende projekt er udviklet og afprøvet en metode til at udvikle ressourcerelaterede Ecodesign-kriterier for tekstiler, og der er desuden foretaget en simpel overførelse af processen på møbler.

Kriterier for materialers ressourceeffektivitet findes allerede i miljømærkesystemer som Svanen og Blomsten, som sigter på at styrke de bedst performende produkter. Ecodesign Direktivet etablerer derimod minimumstandarder, hvorfor disse kriterier må være mindre stringente end miljømærkekriterier og udvikle sig over tid med henblik gradvis forbedring af produkter og rettidig information til producenter.

Der er i projektet udarbejdet en liste over sådanne potentielle kriterier inden for temaerne holdbarhed, genbrug, reparation og genanvendelighed. Kriteriesættet kan danne udgangspunkt for den egentlige udarbejdelse af ecodesign-kriterier i en fremtidig arbejdsgruppe under Ecodesign Direktivet.

I projektet er gennemført en screening af de potentielle miljømæssige gevinster ved de foreslåede kriterier, og der er identificeret tre overordnede ruter til opnåelse heraf:

- $\quad$ Øge den aktive levetid for produkter og fortrænge ny produktion.

- Fortrænge udvinding af råmaterialer via brug af genanvendte materialer.

- Endre vaner ift. vask for at reducere brug af vand og energi. 
Ved anvendelse af denne metode er den øverste grænse for drivhusgasemissionsbesparelser, hvis de foreslåede kriterier implementeres på EU niveau, estimeret til 85 millioner ton $\mathrm{CO}_{2}$-ekvivalenter per år. De opnåede besparelser er afhængige af de endelige grænseværdier for kriterier og respons på deklarationer.

Projektet har illustreret, at det er muligt at formulere relevante kvalitative og kvantitative Ecodesign-kriterier for ikke-energi-relaterede produktgrupper via følgende metode:

- Danne et tværfagligt team.

- Definere anvendelsesområde for tekstiler.

- Udføre litteraturstudie.

- Teste første udkast til kriterier med nøgleaktører i branchen.

- Udarbejde endelige Ecodesign-kriterier. 


\section{Annex A}

Table 7: Participants at the workshop on ecodesign requirements for textiles held at the Danish EPA, 2 May 2017.

\begin{tabular}{|c|c|c|c|}
\hline Organisation name & Country & Representative & Expertise \\
\hline Kvadrat & DK & Jette Lindgaard & Ambitious home textile brand \\
\hline Bestseller & DK & Katrine Milman & Large clothing brand \\
\hline DAFI & DK & Tobia Harboe & Working on ECAP eco-design projects \\
\hline Ecolabel Denmark & DK & Heidi Belinda Bugge & $\begin{array}{l}\text { Ecolabel standards for textiles - currently } \\
\text { working on new Swan for textiles } \\
\text { including design for reuse/recycling }\end{array}$ \\
\hline CBS & DK & Kerli Hvass & $\begin{array}{l}\text { Expert in textiles and textile business } \\
\text { models }\end{array}$ \\
\hline Design School Kolding & DK & Vibeke Riisberg & Design for longer life \\
\hline IVL & SE & Maria Elander & $\begin{array}{l}\text { Technical and process limitations on } \\
\text { recycling }\end{array}$ \\
\hline RISE & SE & Hanna de la Motte & $\begin{array}{l}\text { Recycling technology and processes } \\
\text { expert }\end{array}$ \\
\hline $\begin{array}{l}\text { TEKO, Swedish Industry } \\
\text { Organisaiton for textiles }\end{array}$ & SE & Weronika Rehnby & Textile and Environmental expert \\
\hline Danish EPA & DK & $\begin{array}{l}\text { Gert Søndergaard } \\
\text { Hansen }\end{array}$ & Ecodesign \\
\hline Danish EPA & DK & Emilie Mille Müler & End of life textiles and policy \\
\hline PlanMiljø & DK & Bjørn Baver & Project Manager and ecodesign expert \\
\hline PlanMiljø & DK & David Watson & $\begin{array}{l}\text { Textile use, reuse and recycling and } \\
\text { environmental impacts of textiles }\end{array}$ \\
\hline PlanMiljø & DK & Anja Charlotte Gylling & Textiles expert \\
\hline VTT & $\mathrm{FI}$ & Catharina Hohenthal & Environmental impacts of textiles \\
\hline Swerea & SE & Sandra Roos & Chemicals in textiles \\
\hline Swerea & SE & Anna-Karin Jönbrink & Ecodesign \\
\hline
\end{tabular}


Nordic Council of Ministers

Nordens Hus

Ved Stranden 18

DK-1061 Copenhagen K

www.norden.org

\section{Potential Ecodesign Requirements for Textiles and Furniture}

A large part of the lifecycle environmental impacts of a product are determined at the design stage, why The EU Eco design Directive's potential for application to non-energy related themes has come under the spotlight in recent years with Nordic countries at the forefront.

In this report potential eco design requirements that can be drawn up for non-energy-related products are in focus. Textiles are here used as an example, and a light application of the approach has subsequently been applied to the furniture sector. Clothing and home textiles were chosen due to significant wastage in the value chain due to fast fashion, dropping quality and relatively low repair and reuse rates.

The project was initiated and financed by the Nordic Council of Ministers and led by its Working Group for Sustainable Consumption and Production. A separate Policy Brief (ANP2018:739) is also published. 